\title{
Seismic Hazard in Tien Shan: Basement Structure Control Over the Deformation Induced by Indo-Eurasia Collision
}

\author{
Buslov, Mikhail M. ${ }^{1}$ and De Grave, Johan ${ }^{2}$ \\ IInstitute of Geology and Mineralogy SB RAS, Novosibirsk, \\ ${ }_{2}^{2}$ Department of Mineralogy \& Petrology, Geological Institute, Ghent University, Gent, \\ ${ }^{1}$ Russia, \\ Belgium
}

\section{Introduction}

The Tien Shan are an active intracontinental mountain belt that is part of the Central Asian Orogenic System (fig. 1). In general the mountain belt is composed of E-W trending ranges, separated by (sub)-parallel intramontane depressions. The western part of the Tien Shan is for a large extent situated in the Republic of Kyrgyzstan, while the eastern part is located in China. The Tien Shan can be regarded as a mobile belt between two rigid micro-continent or microplates: to the south this is the Tarim plate, to the north, the Aktyuz-Boordin (which in fact represents the southern part of Kazakhstan-Junggar plate) (fig. 2). The Tien Shan belt was formed during the Palaeozoic closure of the Turkestan Ocean [Allen et al., 1992; Gao et al., 1998; Chen et al., 1999; Brookfield, 2000]. Island-arc systems and micro-plates converged with the northern margin of Tarim and were accreted to Tarim in the Middle to Late Palaeozoic. Final closure of the Turkestan oceanic basin was accomplished in the Late Palaeozoic, in the Permian, when the Tarim and Tien Shan units collided with the Kazakhstan-Junggar plate [Laurent-Charvet et al., 2002; Van der Voo et al., 2006; Yang et al., 2007]. At this time, in the Permo-Triassic, this entire assemblage was also docked to the Siberian continent further north in present-day co-ordinates [Carroll et al., 1995; Levashova et al. 2007] and together these amalgamated terranes formed one of the nuclei of the current Asian continent. This Palaeozoic collision-accretion produced two ophiolite- and UHP-rock bearing suture zones [Allen et al., 1992; Zhang et al., 1993; Gao et al., 1998; Zhang et al 2002a; 2002b; Bazhenov et al., 2003; John et al., 2008]. During the various subduction and accretion episodes, the Tien Shan units were vastly intruded by granitoids [Solomovich \& Trifonov, 2002; Mao et al., 2004; Konopelko et al., 2007; Solomovich, 2007; Pirajno et al., 2008; Van der Voo et al., 2006; Kröner et al., 2008]. An example of these is the extensive northern Kyrgyz granitoid batholith that is mainly of Ordovician - Silurian age, although smaller Permian plutons are found as well.

The basement of the Tian Shan consists of the Issyk-Kul (or Central Tien Shan or Ili) and Aktyuz-Boordin microcontinents. They are composed of Paleoproterozoic strongly metamorphosed rocks, covered by Neoproterozoic and Paleozoic volcanogenic-sedimentary and sedimentary rocks [Buslov et al., 2003; Mao et al., 2004; Konopelko et al., 2007; Solomovich, 2007; Wang et al., 2007a; 2007b] 


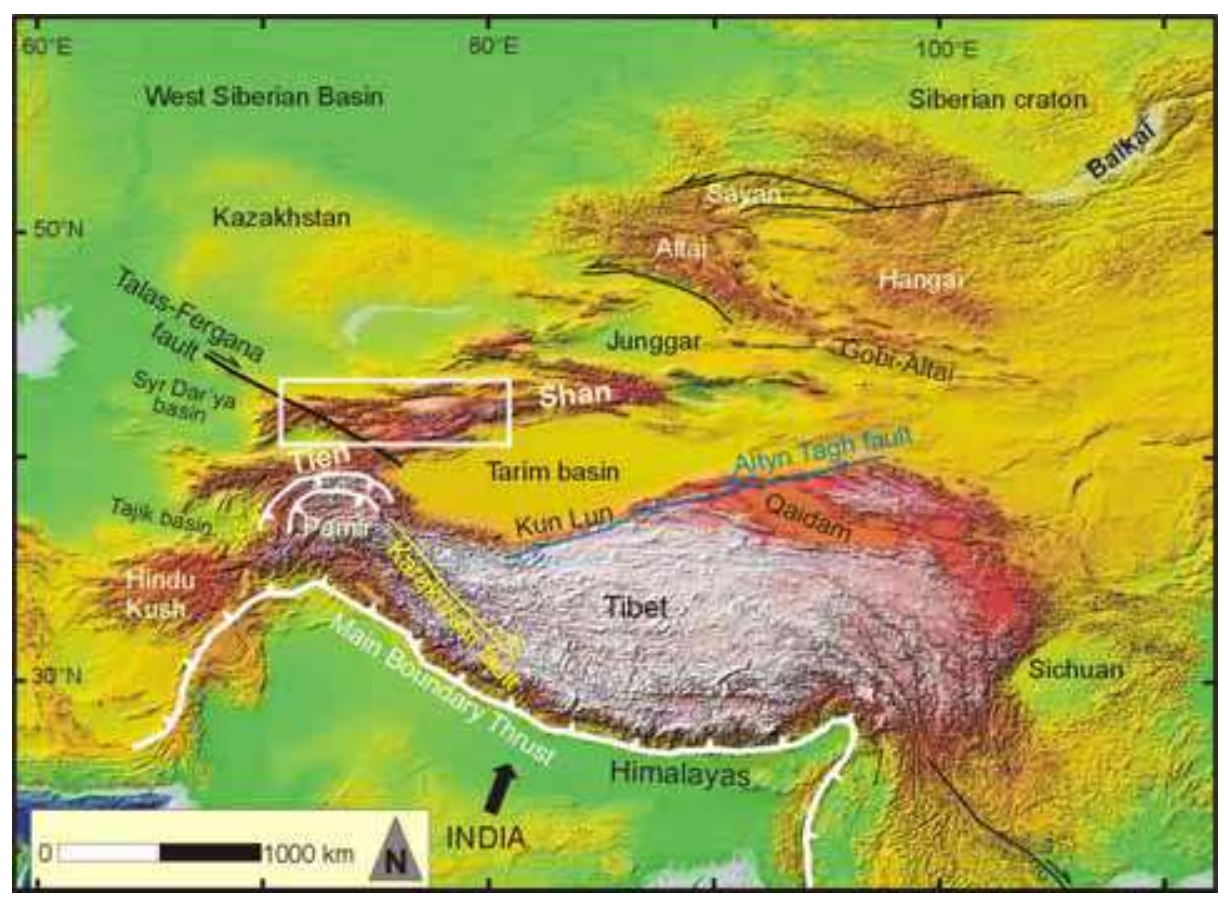

(a)

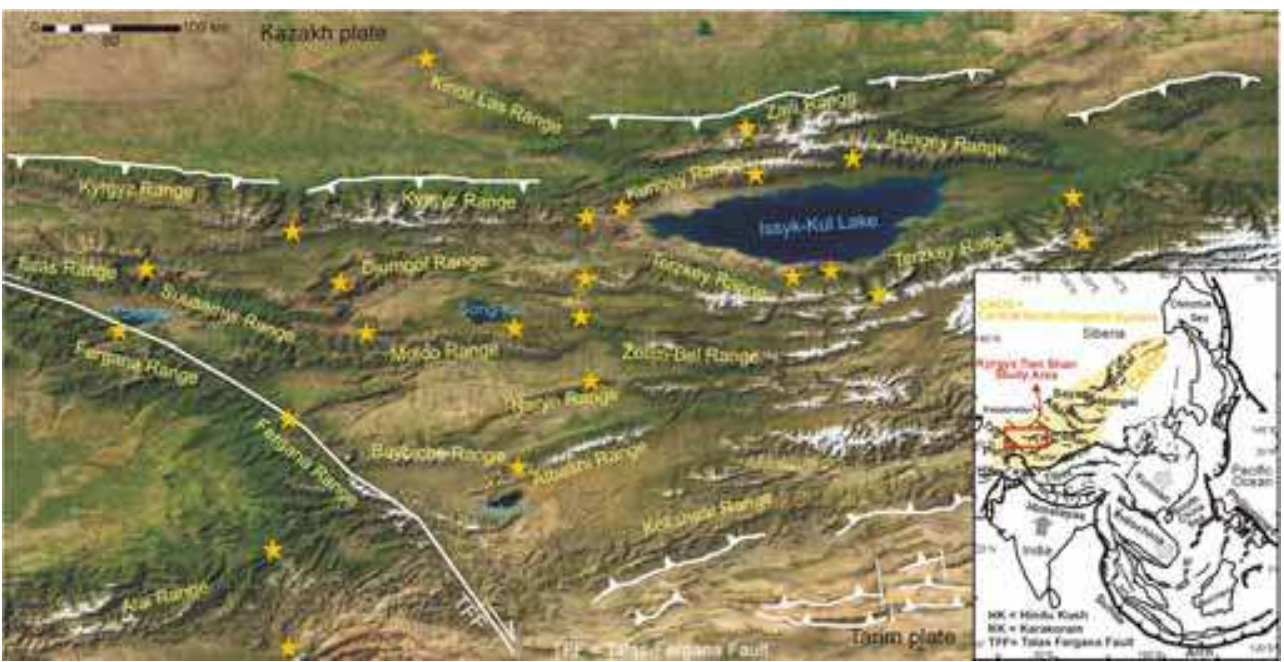

(b)

Fig. 1. (a) General location and setting of the (Kyrgyz) Tien Shan in the intracontinental Central Asian Orogenic System (CAOS). The white box corresponds to the position of Figure 1b; (b) Morphology and mountain ranges of the Kyrgyz Tien Shan. Stars indicate sample localities for geochronological investigations (see next chapter). 
The ancestral Late Palaeozoic - Early Mesozoic Tien Shan belt was reactivated in the Late Mesozoic and a new mountain belt was built at this time along the inherited structural fabric. This is clearly illustrated by the foreland sediments of this Mesozoic Tien Shan range: Jurassic to Cretaceous sediments accumulated to several kilometre-thick foreland deposits in the Junggar (north) and Tarim (south) basins [Chen et al., 1991; Hendrix et al., 1992; Graham et al., 1993; Carroll et al., 1995; Cogné et al., 1995; Métivier \& Gaudemer, 1997; Hendrix, 2000]. Also, the current fault-controlled intramontane basins - such as the Issyk$\mathrm{Kul}$ basin - were formed as shown by their basal Jurassic and Cretaceous sequences that unconformably overlie the Palaeozoic basement [Cobbold et al., 1994]. After a period of Late Cretaceous and Early Cenozoic quiescence, the Tien Shan were again subjected to reactivation and finally evolved to the present-day intracontinental mountain belt that is still active in a mostly transpressive to purely compressive tectonic regime today [Allen \& Vincent, 1997; Allen et al., 2001; Buslov et al., 2003].

These Late Cenozoic and active tectonics are associated with far-field effects of the IndiaEurasia collision [e.g. De Grave et al., 2007a,b]. Erosion of the modern Tien Shan and the current transpressive to compressive tectonic regime are responsible for the exhumation of the basement-cored ranges as they appear today [Sobel et al; 2006; Oskin \& Burbank, 2007], for the supply of the foreland sediments in the Tarim and Junggar basins and for the evolution of the Tien Shan intramontane basins [Heermance et al., 2007].

The most notable present-day crustal movements and their related strongest earthquakes $(\mathrm{M}>6)$ are concentrated at the boundaries of ancient micro-continents [Buslov et al., 2003, 2007]. The study of the Cenozoic structural position of Precambrian micro-continents, which are covered by think sedimentary units, would allow us to reconstruct the tectonic history of the Central Asian earth crust. Understanding the past tectonic events and processes would help us to study and potentially forecast modern catastrophic geological phenomena.

\section{Problem formulation}

\subsection{Cenozoic tectonics and geodynamics of Central Asia}

The main structure of the Central Asia orogenic system and of the Tien Shan in particular is formed by isometrically outlined Precambrian micro-continents (Tarim, Issyk-Kul, AktyuzBoordin, Junggar, Tuva-Mongolian) surrounded by accretion-collision zones. This complex crustal structure of the Tien Shan has a strong impact on the distribution of strain induced by the India-Eurasia collision. This strain is propagated northward as is indicated by the northward rejuvenation of intracontinental mountain ranges and intramontane basins (fig.2).

These micro-continents are submerged into (ancient) subduction zones and in the presentday structural pattern they appear as sub-vertically aligned rigid "roots" occurring as columns in the relatively softer matrix of the folded zones surrounding them. Since the Early Cenozoic initiation of the ongoing India-Eurasia collision, the Central Asian crust has been tectonically reactivated and its pre-Cenozoic structure appears to have been separated into 1) micro-plates or micro-continents overlain by Cenozoic sediments and 2) active fault zones in accretion-collision zones and their associated deformation systems or mountain ranges. The most important factors controlling the propagation of crustal deformation are firstly the presence of rigid micro-continents hosted by "soft" folded matrix and secondly of mantle plumes or at least diapirs of heated material and micro-plates rotating and migrating over so-called "plume heads" [Dobretsov et al., 1996; Buslov et al., 2003; Buslov, 2004]. 

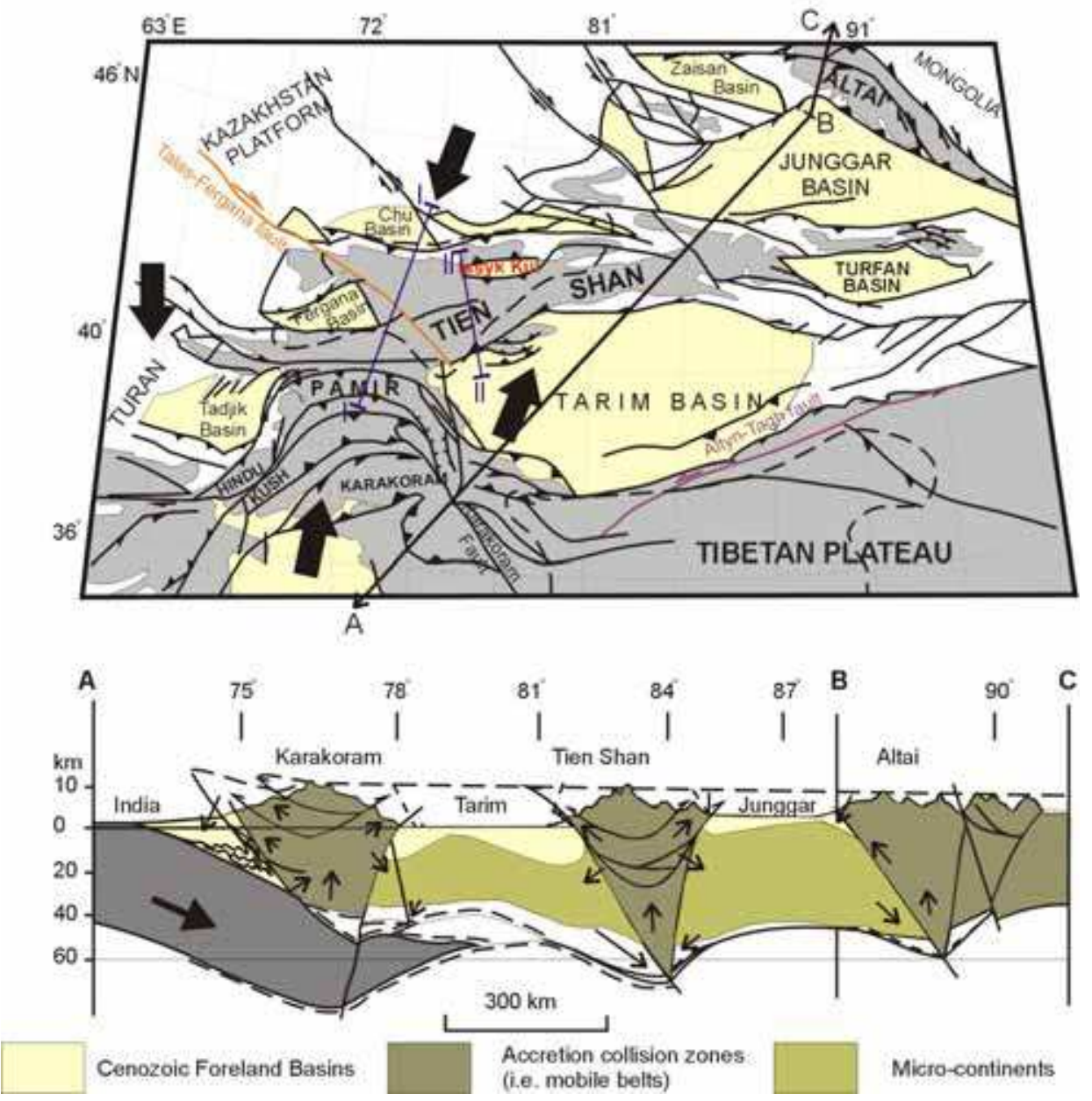

Fig. 2. Schematic Cenozoic tectonic situation and cross section (ABC) through the Central Asian Orogenic System, from India, over the Tien Shan, to the Altai region in South Siberia.

Two distinct deformation pulses have been recognized in the Cenozoic evolution of Central Asia for the period of 35-0 Ma based on new and published GPS, magneto-telluric, seismic, thermochronologic, structural and paleogeographic data on the regions of Altai, Transbaikalia, Tien Shan, Pamir, Himalaya and Tibet [Dobretsov et al., 1996; Buslov et al., 1999, 2003, 2007; Buslov, 2004; Abdrakhmatov et al., 1996, 2001; Aitchison et al., 2007; Avouac \& Tapponnier, 1993; De Grave \& Van den haute, 2002; Molnar \& Tapponnier, 1975; De Grave et al., 2004, 2007a, b, 2008; Sobel et al., 2006; Tapponnier \& Molnar, 1979].

The first deformation pulse (35-5 Ma) started relatively soon after the collision of India. This pulse is characterized by the indentation of the Pamir indenter resulting in the formation of high mountains in Tien Shan (in particular around the Issyk-Kul micro-continent) and around the Junggar plate. The reactivated basement faults and the mantle plume or diapir beneath the Tien Shan resulted in the tectonic layering of the lithosphere. During this pulse, 
the zone of compression and orogeny gradually extended northwards, away from the Indian collision zone and Pamir indenter to the Tien Shan, and then changing its direction somewhat to the northeast, extending over several thousands of kilometers from the Tien Shan, over Altai-Sayan to the Baikal rift zone. The deformation transmitted to such vast distances by the so-called "domino principle" (Dobretsov et al., 1996).

The second deformation pulse (5-0 Ma) was manifested in an EW-striking zone of $\sim 600-1000 \mathrm{~km}$ wide extending from the Pamir and Tarim on one hand to the Siberian craton on the other. At this time, convergence and deformation induced mountain growth between these two rigid structures. At the present time this area is one of the most tectonically active parts of the earth's crust in Central Asia (Buslov et al., 2008).

In the latest Neogene - Early Quaternary mountain growth reached its peak over the whole territory of Central Asia resulting in the formation of continental molasse and catastrophic seismic events (earthquakes and landslides). Thus, the period of the NE gradual (semielastic or ductile) deformation transmitted from the Pamir and Tarim was followed by a period of brittle deformation and crustal hummocking or buckling over the whole territory of Central Asia between the Pamirs and the Baikal rift zone. This resulted in the formation of a strained zone between the active indenter of the Pamirs and the Siberian passive craton. The highest rates of displacement have been recorded within this zone: $20 \mathrm{~mm} /$ year in the Southern Tien Shan (northward migration), $10 \mathrm{~mm} /$ year in the Ukok plateau of the central Altai-Sayan (NE vector), 2-6 mm/year in the Northern Tien Shan (W and SE), $2 \mathrm{~mm} /$ year in the northern and southern parts of the Altai-Sayan area (northward and southward movements, respectively).

\subsection{Tectonic layering of the Kyrgyz Tien Shan lithosphere and seismicity}

The thrusting of the Tarim plate under the Southern Tien Shan and of the Pamirs onto the SW Kyrgyz Tien Shan results in the compression of the upper Tien Shan crust with a maximum velocity of 10-15 mm/yr (fig. 3), whereas India moves to the north with a velocity of $50 \mathrm{~mm} / \mathrm{yr}$ relative to Central Asia and the Tien Shan in particular (Avouac et al., 1993; Avouac \& Tapponnier, 1993). We suggest that a part of the convergence was accommodated by the formation of and flow in a viscous-elastic layer in the middle section of the Tien Shan crust. The deformation in the upper crust was mainly manifested along the Talass-Fergana fault and the strike-slip belts delineating and bounding the micro-continental fragments (fig. 3; cross-section I-I) as described for the Issyk-Kul area for example.

This tectonic layering of the Kyrgyz Tien Shan lithosphere implies the existence of plasticviscous layers. Possibly, the layers can be related to the rotation of the SW Tien Shan block and the underthrusting of the Tarim plate and the indentation of its basement into the middle crust of the Tien Shan. This can explain the fast slip and deformation of the upper $(20-30 \mathrm{~km})$ crustal section.

Seismic S- and P-wave studies (fig. 3; cross-section I-I) show 10-20 km thick nearly horizontal wave-guide layers in the lower $(35-50 \mathrm{~km})$ and upper $(10-20 \mathrm{~km}) \mathrm{crust}$ of the Tien Shan (Bakirov et al., 1996; Sabitova and Adamova, 2001). These thick seismic wave-guide layers are however absent beneath the Fergana Basin and adjacent flat areas in the western Tien Shan. Similar wave-guide lenses are again found in the upper crust at a depth of 10-20 $\mathrm{km}$, north of the Pamirs. The lower layer abruptly ascends to a shallower depth of $15-20 \mathrm{~km}$ near the Talass-Fergana fault. The southern part of the lower wave-guide is consequently uplifted $20 \mathrm{~km}$ relative to the northern part. Near the Tarim plate and NE of the TalassFergana fault, the wave-guide occurs at a depth of 20-40 km (fig. 3; cross-section I-I and II- 
II). Near the southern margin of the Issyk-Kul microcontinent the northern extremity of the wave-guide is also located deeper, somewhat $15 \mathrm{~km}$ lower than its shallow southern occurrence (fig. 3; cross-section II-II).
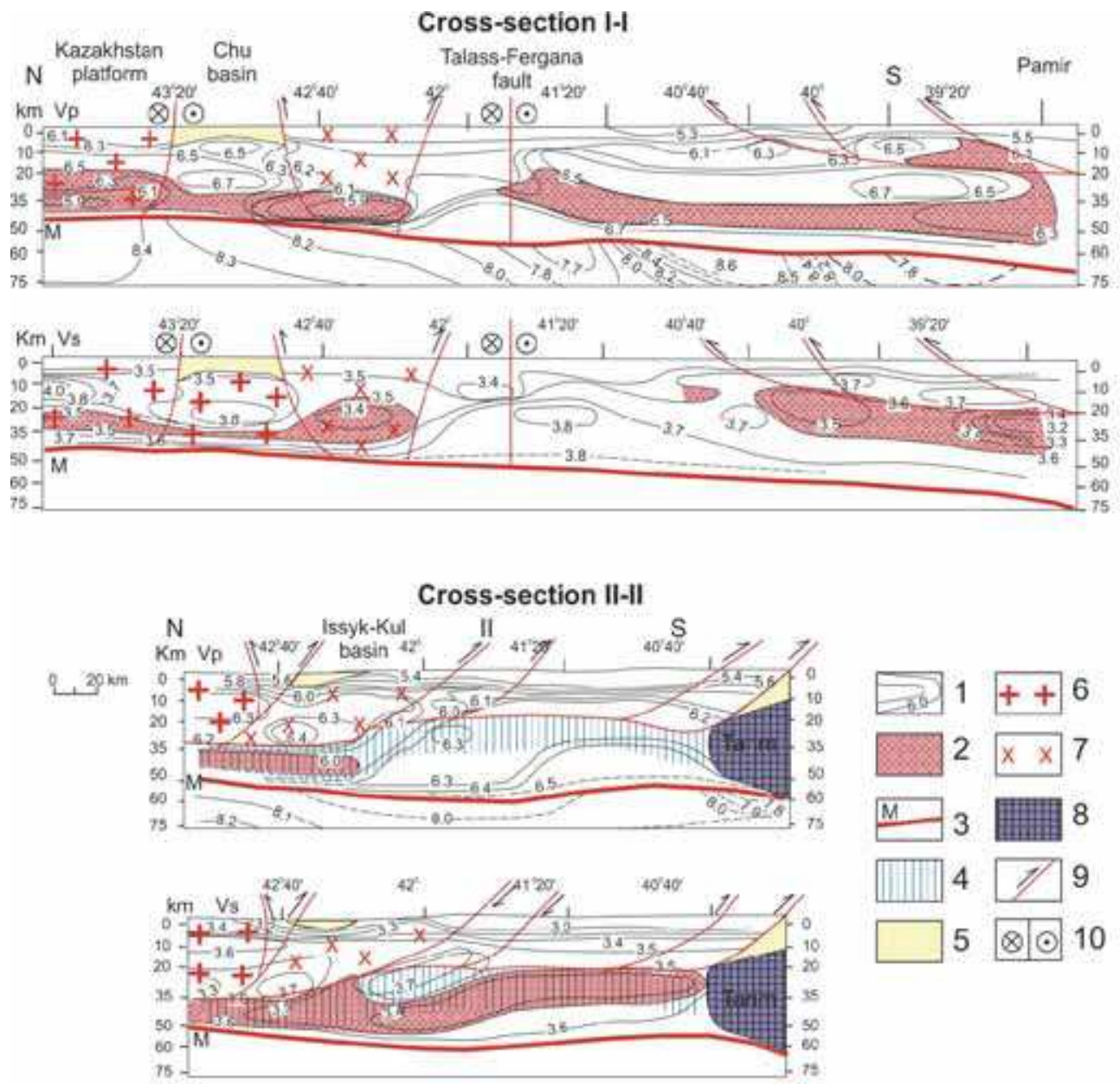

Fig. 3. Cross section I-I and II-II (locations indicated on figure 2) through the crust and upper mantle beneath the Kyrgyz Tien Shan (geophysical data after Bakirov et al., 1996): 1 - Seismic wave velocity iso-lines; 2 - low seismic wave velocity zones; 3 - Moho discontinuity; 4 - high-conductive layers; 5 - Cenozoic basins; 6 - Kazakhstan platform (plate); 7 - Issyk-Kul micro-continent; 8 - Tarim micro-continent; 9 - thrust faults; strike-slip faults.

Magneto-telluric (MT) studies in the Tien Shan (Trapeznikov et al., 1997; Rybin et al., 2004, 2008) also indicate the presence of the aforementioned layers and lenses. Next to seismic wave-guide characteristics discussed above, these layers and lenses exhibit a high electric conductivity. The profiles in figure 3 show the position of the low seismic wave area 
(obtained by seismic data) and high conductivity layers (based on magneto-telluric data). There is a good correlation between the results of these different methods. A 15-25 km thick layer identified by MT, is located at a depth of $35-50 \mathrm{~km}$ to the north of the Issyk-Kul microcontinent and at a shallower depth of $20-35 \mathrm{~km}$ to its south. Oblique wave-guides mark the southern border of the Issyk-Kul micro-continent. Southwards, the wave-guide is located at the same depth as the basement of the Tarim micro-continent $(20-50 \mathrm{~km})$. The occurrence of these viscous layers would restrict the depth of faulting, and consequently the depth of earthquake hypocenters. Hypocenters of all Tien Shan earthquakes are indeed limited to a depth of less than 10-20 km (Sabitova and Adamova, 2001; Bragin et al., 2001) because obviously tectonic strain cannot exist in the viscous-plastic medium identified by the geophysical techniques.

There are three main seismically active regions in the western Tien Shan and Pamirs: the north Tien Shan (NTS), the south Tien Shan (STS) and the Pamir-Hindu Kush (PHK) (Fig. 4). The NTS generally is a low-active seismic zone, although large historical earthquakes as the 1885 Belovodskoye $(M=6.9)$, the 1887 Vernen $(M=7.3)$, the 1889 Chilik $(M=8.3)$, the 1911 Kebin (Kemin) $(M=8.2)$, the 1946 Chatkal $(M=7.5)$, and the 1992 Suusamyr $(M=7.5)$ have occurred. The 1902 Kashgar $(M=7.8)$, the 1907 Karatag $(M=7.3)$, the 1949 Khait $(M=7.4)$, and the 1974 Markansui $(M=7.3)$ earthquakes in the STS zone occurred against a background of high seismic activity. This is nicely illustrated by the recent (5 October 2008) $\mathrm{M}=6.6$ STS earthquake at the Pamir/Tien Shan thrust system near the Kyrgyz-Tajik border town of Nura that killed at least 72 people. The PHK is the most seismically active zone in Central Asia. It can be traced along the Pamir indenter front and has a characteristic S-shape. The PHK zone for example generated the 1909 Hindu Kush earthquake $(\mathrm{M}=8.0)$ with a hypocenter at $230 \mathrm{~km}$, several dozen $7.0<\mathrm{M}<7.5$ tremors with shallower focal points and thousands less strong events. The lithosphere beneath the PHK zone is unstable and is continuing to submerge into the upper mantle, providing very deep seismic sources at depths of up to $300 \mathrm{~km}$. The seismic sources of the STS and NTS zones on the other hand are a lot more shallow and are located in the upper crust, mostly at a depth of 15 to $20 \mathrm{~km}$, as they are constrained at depth by the viscous, plastic layering in the Tien Shan crust and lithosphere as described earlier.

Of special importance is the relation of the STS and NTS seismic zones to the mountain ranges bordering the Precambrian Issyk-Kul micro-continent. The aforementioned strong earthquakes (NTS) and high-velocity active fault movements are connected to the building of these mountain ranges. These events are clearly basement controlled as they are transpiring at the rigid body (micro-continent) borders. We can view the STS seismic events in the same context, with the Tarim microplate as rigid body thrusting underneath the Tien Shan.

\section{Problem solution}

\subsection{Basement structure control over the deformation induced by Indo-Eurasia collision}

As mentioned, micro-continents form an important feature in the tectonic collage of the Central Asian Orogenic System and were submerged into subduction zones during the formation and evolution of the Central Asian crust. In the present-day structural pattern of Central Asia, these micro-continents have sub-vertically aligned rigid roots occurring as columns in the relatively softer matrix of folded zones or mobile belts. The India-Eurasia collision, and the ongoing indentation of the Indian plate into the Eurasian continent, 


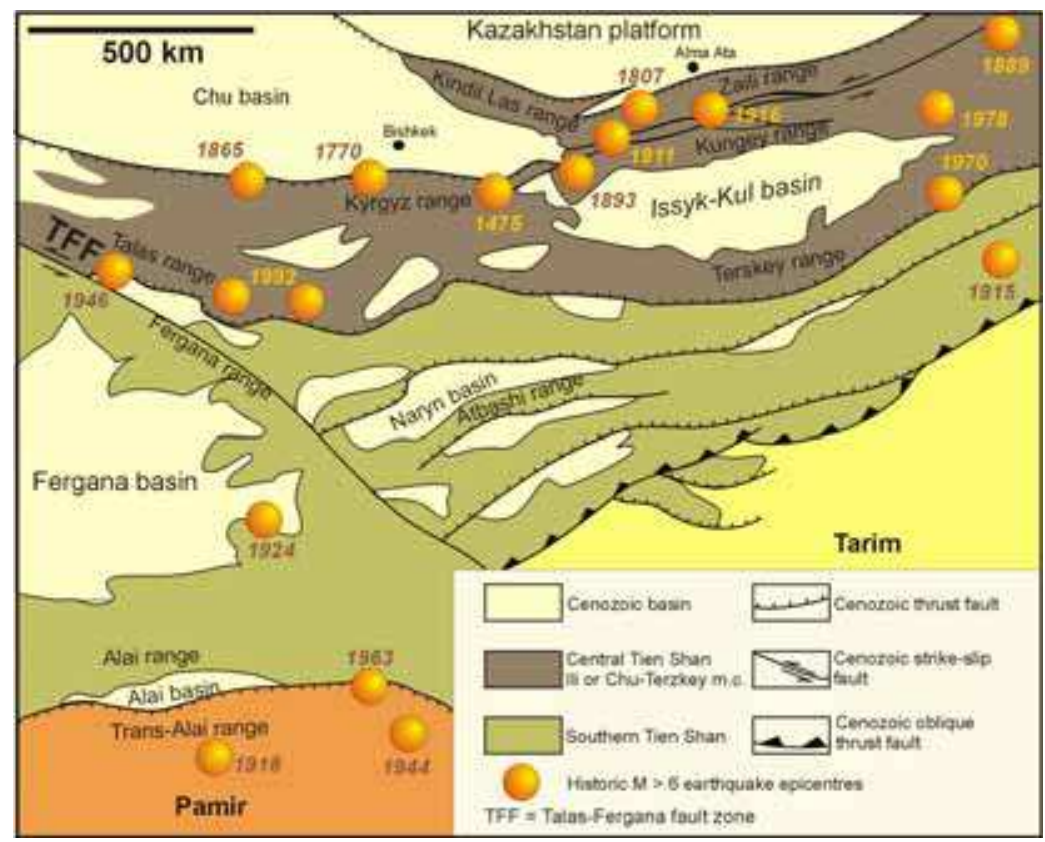

(a)

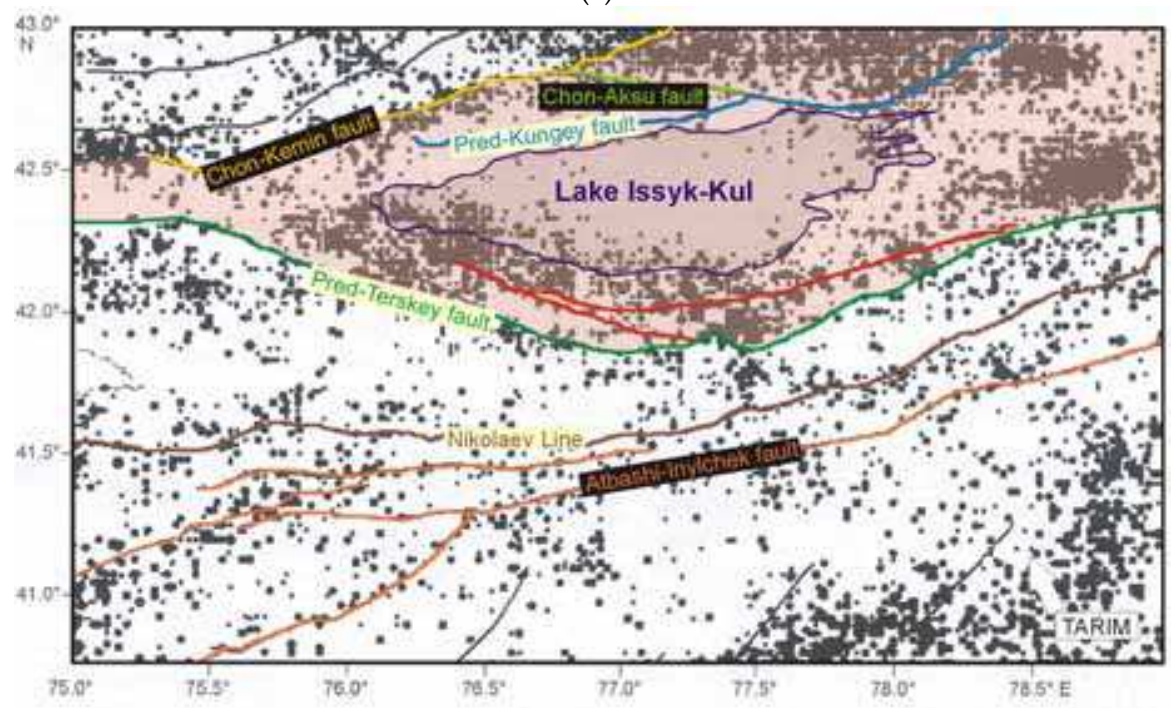

(b)

Fig. 4. (a) Present-day tectonic scheme of Kyrgyz Tien Shan with location of historic $M>6$ earthquake epicentres. Most of these occurred around the edges of the Issyk-Kul (or Central Tien Shan or Ili) micro-continent. (b) M > 2 earthquake epicenters (black dots) since 1970 in the eastern Kyrgyz Tien Shan (modified after Tychkov et al., 2008). Again in this case, the epicenters cluster around the edges of the Issyk-Kul micro-continent (shaded pink). 
reactivated the pre-Cenozoic structure of the Central Asian crust and separated it into (1) more or less undeformed micro-plates or micro-continents overlain by Cenozoic sediments and (2) active fault zones in accretion-collision zones and their related mountain systems (fig. 2). The most important factor controlling the propagation of crustal deformation into the Asian continental interior, away from the Indian convergence zone, is specifically the presence of these rigid micro-continents within the softer folded matrix [Dobretsov et al., 1996; Buslov et al., 2003; 2004; 2007].

In particular, during the Cenozoic, two factors affected the structure and geodynamics of the Tien Shan during its reactivation from the south: (1) thrusting of the Pamirs (west) and (2) under-thrusting of the Tarim plate (east) (fig. 2-4). These two processes are responsible for the formation of different structural-geodynamic Tien Shan provinces and are separated by the Talass-Fergana fault zone [Khudoley, 1993; Bakirov et al., 1996; Trapeznikov et al., 1997; Zubovich et al., 2001; Abad et al., 2003; Buslov et al., 2003, 2007]. These tectonic processes responsible for the complicated modern structure of the Tien Shan are still active. For example, the Issyk-Kul (or Central Tien Shan or Ili) micro-continent that hosts the Issyk-Kul basin, had been a homogenous structure during a long period prior to the latest Cenozoic, while there is evidence that young deformation reached its central part as late as the Quaternary [Trofimov, 1990]. At present, as in the case for many other Central Asian regions with rigid micro-plates in the local mobile belts, the strongest deformation processes in the Kyrgyz Tien Shan are recorded along the Issyk-Kul micro-continent margins. These margins are defined by a system of overriding thrusts that promote the further subsidence of the Issyk-Kul basin bottom and the formation of a pull-apart structure (fig. 5, 6) within the central Issyk-Kul basin [Buslov et al., 2003, 2007].

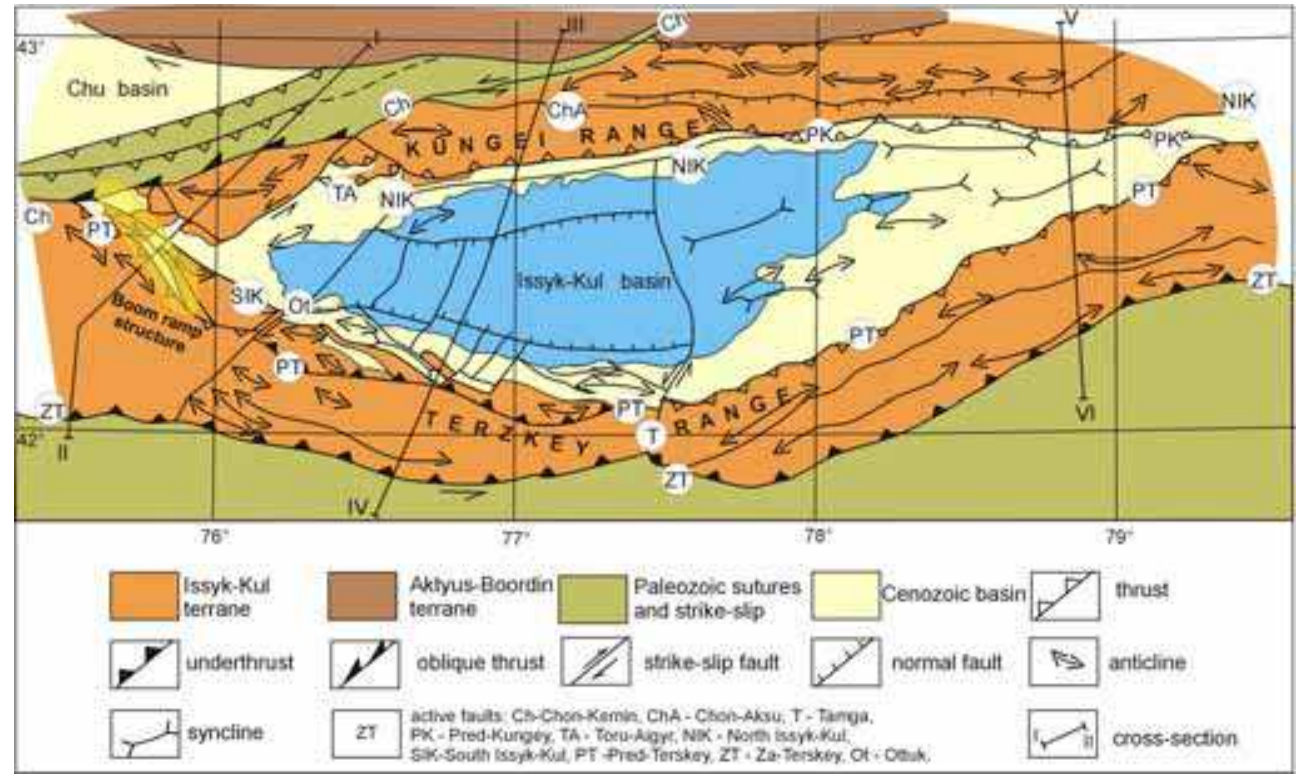

Fig. 5. Structural sketch map of the Issyk-Kul Basin and its basement, with positions of cross-sections from fig. 6. 

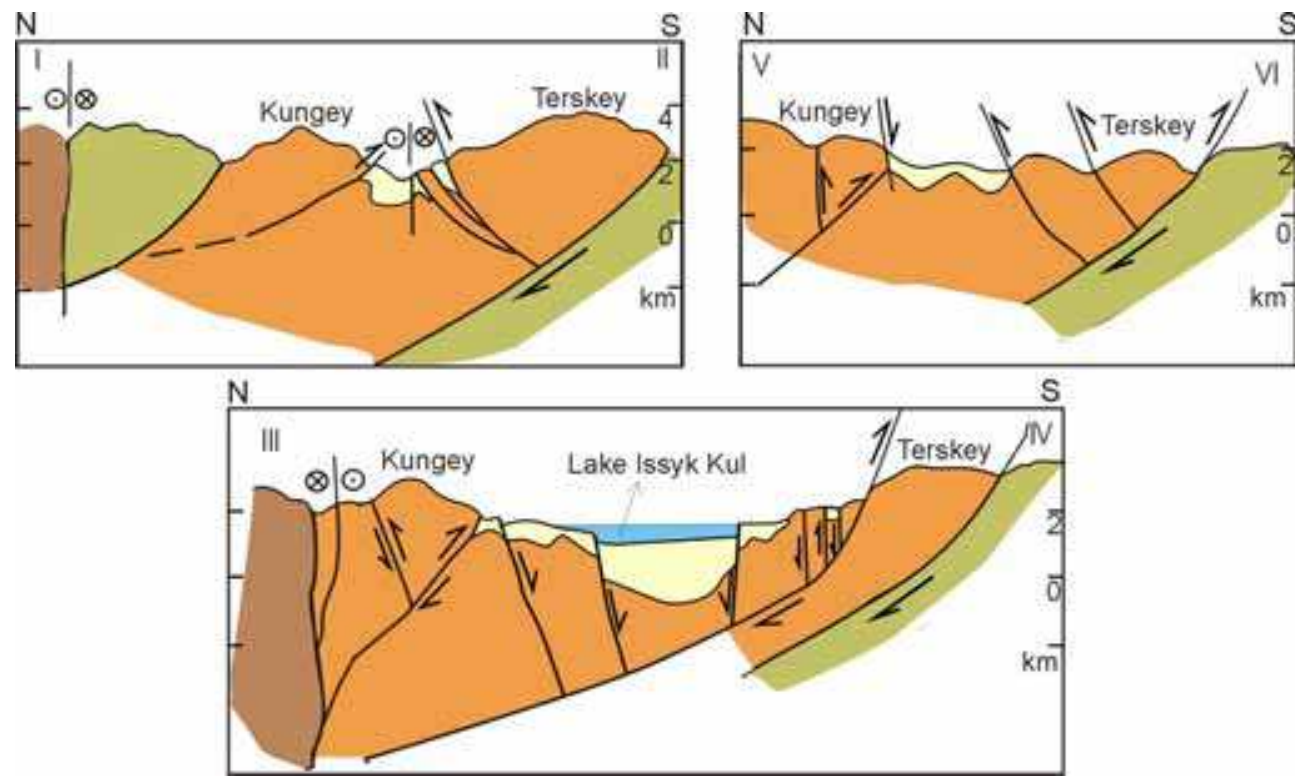

Fig. 6. Cross-sections across the western, central and eastern parts of the Issyk-Kul Basin (locations on figure 5).

The structural pattern of the pre-Mesozoic Tien Shan basement clearly influences the Mesozoic and Cenozoic reactivation of the Tien Shan orogen. This basement is highly heterogeneous and consists of the relatively rigid blocks of the Precambrian Tarim plate, the Issyk-Kul (or Central Tien Shan or Ili) micro-continent [Wang et al, 2007a; 2007b], and the Aktyuz-Boordin microcontinents (actually a part of the southern Kazakhstan platform: Zaili and Kindil Las ranges) [Djenchuraeva et al., 2008]. Their rigid bodies are enclosed in a more ductile, easier to deform matrix of Palaeozoic accretion-collision belts. It seems that these rigid blocks in the northern Tien Shan are displaced in the mobile matrix that surrounds them at variable velocities and directions with respect to each other. These displacements are considered an active far-field tectonic response to continued India-Eurasia convergence, and produces large earthquakes at the rigid body boundaries. All the epicentres of these large earthquakes are located within a narrow linear zone between the Aktyuz-Boordin and Issyk-Kul micro-continents, while other epicentres of $M>6$ earthquakes [Wang et al., 2004; Tatevossian, 2007; Bourdeau \& Havenith, 2008] mark the northern and southern margins of the Issyk-Kul microcontinent (Fig. 4). This indicates that crustal heterogeneity affects the formation of the active structures of the northern Kyrgyz Tien Shan [Buslov et al., 2003; 2004].

The Talass-Fergana fault zone, which is currently the site of dextral strike-slip movements, divides the Kyrgyz Tien Shan into a NE and SW part (fig. 4). As mentioned, two different tectonic mechanisms are responsible for this characteristic geometry: under-thrusting of the Tarim microcontinent under the southern Tien Shan [Neil \& Houseman, 1997; Allen et al., 1999; Yang \& Liu, 2002] and thrusting of the Pamir block onto the southwestern Kyrgyz Tien Shan [Lukk et al., 1995; Pavlis et al., 1997; Burtman, 2000; Coutand, 2002] respectively [Buslov et al., 2003]. The under-thrusting of Tarim and the thrusting of the Pamirs formed the Cenozoic structural pattern of the Tien Shan, but also resulted in the so-called tectonic 
layering of the upper lithosphere [Buslov et al., 2003; Lei \& Zhao, 2007]. Different mechanisms of the Tarim and Pamir convergence were manifested in different time intervals and resulted in strike-slip movements along the Talass-Fergana fault. Of special interest is the fact that the displacement rate along the fault was $10 \mathrm{~mm} / \mathrm{yr}$ during the Late Cenozoic and is as low as $2-3 \mathrm{~mm} / \mathrm{yr}$ at present [Burtman et al., 1996; Meade and Hager, 2001]. This could be explained by the fact that the Tarim and Pamir convergent forces on the southern Tien Shan edges presently nearly cancel each other out (low slip rates), while earlier during the last $10 \mathrm{Ma}$ the strain of the Pamir indentation dominated and resulted in the dextral strike-slip reactivation of the fault with higher displacement rates.

Given a total crustal shortening of $200 \pm 50 \mathrm{~km}$ and the present-day shortening rate of 20 $\mathrm{mm} / \mathrm{yr}$, the northern Tien Shan could have been constructed within the last $10 \mathrm{Ma}$ [Abdrakhmatov et al., 1996]. This latter study also suggest that the recent outspoken uplift of the Tien Shan could be the result of a marked increase in horizontal compressive forces following the abrupt rise of the Tibetan Plateau, as proposed by England and Houseman (1989). Apatite fission-track thermochronology, structural modelling and magnetostratigraphy in the Kyrgyz Range (and adjoining ranges) and the Chu Basin in the northern Kyrgyz Tien Shan further showed that a first strong phase of rock uplift and deformation affected the northern Tien Shan 10-11 Ma ago, and a second accelerated phase occurred 5-3 Ma ago [Burbank et al. 1999; Bullen et al., 2001; 2003; De Grave et al., 2004; Sobel et al., 2006]. The latter acceleration is also expressed in the stratigraphy by a marked change in sedimentary environment in the Late Pliocene-Early Pleistocene: thick sequences of coarse conglomerates, sedimentary gaps and tectonic unconformities are observed [Cobbold et al., 1994; Abdrakhmatov et al., 2001].

As mentioned earlier, the Cenozoic tectonic activity of the Tien Shan is assumed to be the effect of the current indentation of India into the Eurasian continent [e.g. Molnar and Tapponnier, 1975; Cobbold and Davy, 1988]. Consequently the collision caused the propagation of deformation to the interior of the continent, resulting in crustal thickening and intracontinental mountain building. The Tien Shan consists of roughly EW-trending mountain ranges (with peaks exceeding $7000 \mathrm{~m}$ ) alternating with sub-parallel sedimentary basins. Major Cenozoic faults mark the EW-trending boundaries between ranges and basins. However, the Talass-Fergana fault zone described above, strikes at an angle to the main structural direction and is oriented NW (fig. 1 trough 4).

The Cenozoic tectonic evolution of a vast part of Asia can be described in terms of the continuing convergence between India and Eurasia. After the initial collision [Dobretsov et al., 1996; Aitchison et al., 2007], India has continued its northward motion at reduced velocity and acts as a rigid indenter penetrating $\sim 2000 \mathrm{~km}$ into Asia to cause postcollisional underplating (India) and uplift (Tibet) [Molnar \& Tapponnier, 1975; Mercier et al., 1987; Cobbold and Davy, 1988; Le Pichon et al., 1992; Avouac \& Tapponnier, 1993; Avouac et al., 1993; Dobretsov et al., 1996].

Orogeny in the Pamir and southern Tien Shan regions started later (post $35 \mathrm{Ma}$, Burtman, 2000) than the incipient Tibetan uplift during the collisional stage and was accompanied in the Late Oligocene by deposition of coarse-clastic, red continental molasse. The Miocene landscape of the Pamirs and the southern Tien Shan was dominated by $<3 \mathrm{~km}$ uplifts and intermittent depressions. In the Pliocene, red molasse gave way to grey molasse deposits as a result of climatic cooling, while the uplifts reached an altitude of 4-5 km. Further Quaternary uplift of the Pamirs and the Tien Shan produced the current typical glacial landscape [Chedia, 1986; Mikolaichuk, 2000; Abramowski et al., 2006; Zhao et al., 2006; Koppes et al., 2008]. 
Mechanisms of the formation of the Cenozoic structure of the Issyk-Kul micro-continental basement and its cover have been established via remote sensing, interpretation of satellite images, structural and geomorphologic studies and paleo-stress analyses. In the PalaeogeneMiocene the Issyk-Kul micro-continent remained relatively stable and about $4 \mathrm{~km}$ of sediments were deposited (Kokturpak, Kyrgyz, Issyk-Kul suites). Lacustrine sediments accumulated in the Palaeogene and lacustrine-proluvial ones in the Neogene-Quaternary mark the initiation of deformation. Clastic material was transported from the growing southern Tien Shan. Some fragments from the northern Tien Shan have been found in the Neogene-Quaternary deposits as well. These deposits point toward extensive Neogene erosion of the surrounding basement, and hence they imply significant denudation and exhumation of the basement. This exhumation is responsible for the cooling of the basement rocks that is observed through low-temperature thermochronologic techniques.

The tectonic activity and the deformation in the northern Tien Shan reached its peak in the Pliocene-Early Quaternary and resulted in the formation of the present-day topography and the strong deformation of the Issyk-Kul micro-continental basement and its Cenozoic cover. The direction of the regional compression changed from NW in the Late Miocene to NS in the Pliocene-Early Quaternary. The southern and northern margins of the micro-continent were hence gradually involved into thrusting and uplift and the surface area of the basin reduced. Ramp structures formed on its western and eastern ends as the mainly Ordovician - Silurian granitoid basement cored ranges were thrust onto the basin margins. The thrusting of these mountain structures over the basin was accompanied by the deposition of molasse-type sediments. Under-thrusting along the Kyrgyz-Terskey zone resulted in the splitting of the southern margin of the microcontinent into several blocks separated by oblique thrusts and strike-slip faults. Strike-slip movements along the Chon-Kemin fault resulted in thrusting and reverse faulting along the northern margin of the Issyk-Kul micro-continent (fig. 5, 6).

Although it has been intensively studied [Chedia, 1986; Trofimov, 1990; Mikolaichuk, 2000; Abdrakhmatov et al., 2002; De Batist et al., 2002; Buslov et al., 2003; Bowman et al., 2004], there is no unanimous view on the recent tectonics of the basin and its recent geodynamic evolution. The Issyk-Kul basin was formed along E-W striking normal faults and transverse faults in the Early and Middle Pleistocene. It had a much larger extension than at present, particularly to the East. It has been suggested that the lake basin originated as a pull-apart structure, which formed due to dextral displacements along strike-slip faults accompanied by regional NS compression [Klerkx et al., 1999]. About $4 \mathrm{~km}$ of sediments accumulated in the basin, the depocenters shifting progressively from east to west. At present, the basin has a trapezoid shape and is bounded by EW-NE-, and NW-striking faults (Fig. 5, 6). Trofimov (1990) argues that the structure of the Issyk-Kul basin evolved by the subsequent collapse of blocks in the west and east - from the periphery towards the center - while the faults and fault blocks in the south and north remained more stable. In an initial stage of recent basin evolution, during the Early and Middle Pleistocene, the displacement along the faults had reached $30-50 \mathrm{~m}$. The normal faults were reactivated in the Late Pleistocene, the displacement reached 50-100 m. Catastrophic collapse of the central part of the lake, which subsided by $200 \mathrm{~m}$, took place in the Middle Holocene. As a result a deep-water basin of almost $700 \mathrm{~m}$ depth formed during the last 10,000 years. This catastrophic collapse is supposed to be the direct cause to the regression of the Issyk-Kul in the Middle Holocene, when its water level rapidly lowered by $100 \mathrm{~m}$ [Trofimov, 1990]. De Batist et al. (2002) however argue that there is no evidence in the architecture of the off-shore sediment deposits to justify the hypothesis of a catastrophic collapse of the central basin floor. 
The structural scheme is clearly different when considering different segments of the basin on a traverse from west, over central to east (fig. 5,6). In the eastern part, which is well exemplified by the Boom syncline (section I-II in fig. 5), the basin has a well-defined ramp structure, delimited at both its northern and southern borders with the basement by thrust faults. Towards the east, the full ramp structure progressively evolves towards a half ramp structure. The northern area (in Russian literature, the western Pri-Issyk-Kul region), the Kungey range is thrust over the basin along the Toru-Aigyr fault [Mikolaichuk, 2000; Korzhenkov, 2000]. At the southern side the lacustrine sedimentary cover is in normal contact with the basement.

In the eastern part (section V-VI in fig. 5, 6), arched-up and linear folds widely affect the Cenozoic cover in the eastern Pri-Issyk-Kul region. The basin and basement are separated by thrusts and reverse faults on both the north and south sides. At the northern side, the TaldySui oblique thrust delimits the basin. In the central part, the structural scheme is different. In the northern part, the Pred-Kungey oblique thrust joins with the Taldy-Sui thrust through the Aksui graben that constitutes the boundary between the east and central part. However, the most important structure of the northern Tien Shan is the NE-striking Chon-Kemin fault zone bounding the Issyk-Kul micro-continent on the north (fig. 5, 6). Recently, the presence of a significant sinistral strike-slip component has been evidenced in the kinematics of the Chon-Kemin fault zone [Delvaux et al., 2001, 2004], although previously it has been interpreted as a reverse fault [Chedia, 1986]. At the southern side, the Pred-Terskey fault zone bounding the Issyk-Kul micro-continent on the south (fig. 5, 6) is characterized by fault planes with complicated kinematics. The segments of the fault zone, which have different fault plane kinematics, are separated by the Tamga and Ottuk faults (fig. 5). The eastern segment - to the east of the Tamga fault - is a thrust: the Terskey range is thrust on the Cenozoic sediments. The middle segment - between the Tamga and Ottuk faults - is an under-thrust. The western segment is again a thrust. The eastern and middle segments are separated from the Pred-Terskey fault by the NS-striking Tamga fault, which sinistral offset is $700 \mathrm{~m}$. The morphology of the Tamga fault is also complicated. At the junction point with the Pred-Terskey fault it is an oblique thrust. To the north, it transfers into a marginal fault (normal fault) of the subsiding trapezoid structure of the Issyk-Kul Basin and Lake. The Cenozoic sediments and Quaternary terraces, south of the lake, are affected by linear folds, as well as EW-striking flexures and reverse faults. Characteristic is the occurrence of numerous flexures and anticline folds with a gentle northern wing and steep-and-short southern wing often broken by faults, exhibiting a reverse sense of movement. The change of kinematic regime along the axis of the basin indicates various expressions of the impact of the NS compression on the Issyk-Kul microcontinent. We consequently propose that the thrusting of the Terskey range under the Issyk-Kul microcontinent resulted in the uplifting of its southern flank and subsidence of its central part. The northward dipping of erosion surfaces of the Terskey range and Cenozoic beds supports this suggestion. The transition zone between the uplifted part of the Issyk-Kul micro-continent (the western Terskey range) and the subsided part runs along the southern shoreline of the lake.

\subsection{Termochronology}

In order to constrain the aforementioned general Meso-Cenozoic geodynamic - tectonic history of the Kyrgyz Tien Shan in an absolute time frame, the crystalline basement rocks of several ranges were sampled for a thermochronological investigation as for example 
performed in the Siberian Altai Mountains [De Grave \& Van den haute, 2002; De Grave et al., 2007b, 2008]. In most cases granitoid basement rocks were targeted for sampling, although a minor amount of metamorphic and metasedimentary samples were collected. Using the apatite fission-track (AFT) dating and modelling $\left(\sim 120-60^{\circ} \mathrm{C}\right)$ approach a continuous time-Temperature, tT-path for the different Kyrgyz Tien Shan mountain ranges can be constructed. All or some of these method were applied to the rocks of the following Kyrgyz Tien Shan mountain ranges (fig. 1b, more or less listed in a N-S sense): Kindil-Las, Zaili, Kyrgyz, Kungey, Terskey, Talas, Suusamyr, Fergana, Jumgöl, Moldo, Dzhetim Bel, Naryn, Atbashi, Alai, Trans-Alai.

In general terms, the data from most samples shows (fig. 7) that this Mesozoic event lasted until the Late Jurassic - Early Cretaceous ( 150-100 Ma). Over the entire Kyrgyz Tien Shan territory the exact timing of this Mesozoic basement cooling shows some scatter, which indicates a possible punctuated or multi-phased driving force for this basement cooling. Given the ages, the specific low-T-sensitivity of the various thermochronologic methods applied, and the punctuated character, we interpret the Jurassic-Cretaceous Kyrgyz Tien Shan basement cooling as exhumation of this basement due to denudation of the overlying bedrock. The denudation and erosion can be associated with a phase of tectonic reactivation of the Tien Shan orogen and rejuvenated mountain building [Graham et al., 1993; Cobbold et al., 1994; Allen \& Vincent, 1997; Métivier \& Gaudemer, 1997; Hendrix, 2000; Li et al., 2004]. This Mesozoic tectonic activity and the resulting sediments are expressed in the field e.g. by Mesozoic embryonic intramontane basins (e.g. Issyk-Kul), still present in the current mountain belt, and their Mesozoic basal sediment load. Also, thick Mesozoic foreland deposits can be traced far into the Tarim, Junggar and Kazakh basins [Carroll et al., 1995; Hendrix, 2000]. In its turn, the Mesozoic reactivation and denudation can be further linked to the contemporaneous Cimmerian orogeny. This orogeny is connected to the convergence and collision of the Cimmerian blocks with the active southern margin of Eurasia. In particular, the punctuated collision of the Pamir-Tibetan blocks in the Jurassic and Early Cretaceous with Tarim/Tien Shan as a result of the closure of the Paleo-Tethys is the most probable cause of the Tien Shan reactivation. Distant effects of the collision events initiated Mesozoic movements along the inherited Tien Shan structures [Allen \& Vincent, 1997].

When these movements ceased and tectonic quiescence was again installed in the Tien Shan region, the Mesozoic Tien Shan orogenic edifice was subjected to sustained erosion and peneplanation during which the underlying basement experienced only moderate exhumation and cooling. This episode is reflected in the regional thermal history reconstruction by modelled AFT data. These models (fig. 7) exhibit Late Cretaceous - Early Cenozoic near-horizontal tT-paths. The models indicate that most of the rocks sampled in the Kyrgyz Tien Shan remained at upper apatite annealing zone (APAZ) temperatures to lower AFT retention temperatures $\left(\sim 80-50^{\circ} \mathrm{C}\right)$, i.e. more or less the temperature interval corresponding to the crustal position the rocks reached at the cessation of Mesozoic tectonic activity and denudation. These tT-paths evoke quiescence and relaxation of the isotherms in the upper crust, and are hence suggestive of the aforementioned period of tectonic stability, peneplanation and red-bed formation.

In general the near-horizontal tT-paths are disturbed by a recent rapid cooling, corresponding to a last phase exhibited by the modelled tT-paths. This phase finally brings the samples to their present-day surface temperatures at their outcrop positions. In particular, this recent cooling brings the temperatures down from upper APAZ - lower AFT 

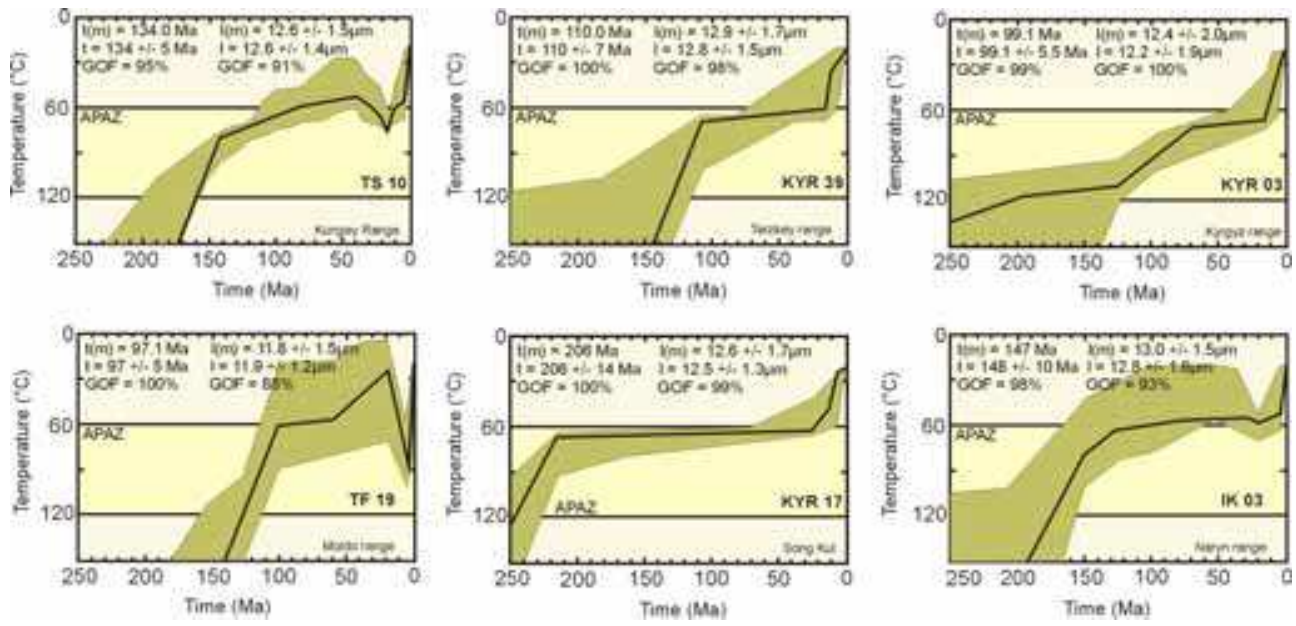

Fig. 7. Examples of thermal history models obtained on AFT age and length data from samples from the northern Kyrgyz Tien Shan batholith. For sample locations see figure $1 \mathrm{~b}$.

retention temperatures to ambient temperatures. The timing of this characteristic is restricted to the Late Cenozoic but shows some scatter between individual samples. Some samples exhibit this peak as early as $20 \mathrm{Ma}$ ago, while others constrain the cooling to the last 5 Ma. However in most cases, it is safe to say that cooling initiated, seemingly in a somewhat poly-phased fashion, during the last 10 to $15 \mathrm{Ma}$. These cooling curves in the models might thus represent the timing of the denudation of the modern Tien Shan orogenic edifice and can be corroborated by several lines of independent geological evidence from such fields as sedimentology [Cobbold et al., 1994; Métivier \& Gaudemer, 1997; Dill et al., 2007], magneto-stratigraphy [Sun et al, 2004; Charreau et al., 2005; 2006; Huang et al, 2006; Ji et al., 2008], geomorphology and structure [Tibaldi et al., 1997; Yin et al., 1998; Burbank et al., 1999; Abdrakhmatov et al., 2001; Thompson et al., 2002; Buslov et al., 2003; Fu et al., 2003; Hubert-Ferrari et al., 2007; Oskin \& Burbank, 2007], geophysics [Trapeznikov et al., 1997; Bielinski et al., 2003; Rybin et al., 2004; 2008], geodesy [Abdrakhmatov et al., 1996; Reigber et al., 2001; Vinnik et al., 2004; Tychkov et al., 2008], and other geochronological studies [Sobel \& Dumitru, 1997; Bullen et al., 2001; 2003; Sobel et al., 2006; De Grave et al., 2007a; Heermance et al., 2007]. We should caution the reader that this Late Cenozoic feature is mainly obtained by modelling the AFT data [Laslett et al., 1987; Ketcham et al., 2000]. Therefore a modelling artefact, recognized in AFT data modelling cannot be ruled out. However, at some places in the Kyrgyz and Terskey ranges reset, Late Cenozoic AFT ages are also found (fig. 8). For the central Terskey range for example, we find Late Cretaceous ages at higher elevations, but close to the Issyk-Kul basin, AFT ages between 17-38 Ma are obtained. In summary and given the strong independent geological evidence we interpret the Late Cenozoic, more specifically, Late Miocene to Plio-Pleistocene (15 - $5 \mathrm{Ma}$ ) and recent (5-0 Ma) cooling pulses as denudation of the current active Tien Shan mountain ranges as a far-field effect of ongoing India-Eurasia convergence. Moreover, this is further underscored by new U-Th-Sm/He dating results on the apatites from the Kyrgyz Tien Shan samples. Results from samples in the eastern Terskey Range yield AHe ages between 10-12 Ma and for the Zaili Range 10-33 Ma. 


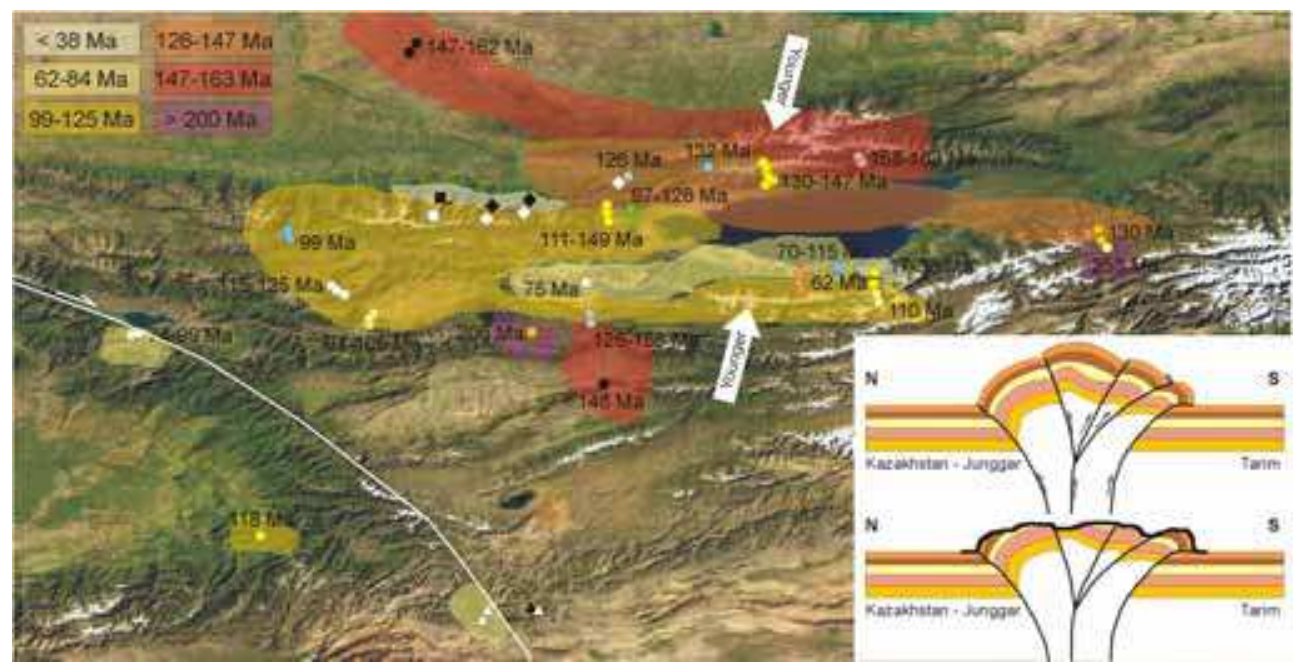

Fig. 8. AFT age zones in the Kyrgyz Tien Shan. Ages tend to get younger towards the more centrally located ranges.

Together with results from similar studies [Hendrix et al., 1994; Van der Beek et al., 1996; Sobel \& Dumitru, 1997; Bullen et al., 2001; De Grave \& Van den haute, 2002; De Grave et al., 2004; 2007a; 2007b; 2008; Sobel et al., 2006; Yuan et al., 2006; Jolivet et al., 2007; Vassallo et al., 2007], these observations seem to suggest that reactivation and deformation in the interior of the Eurasian continent is gradually rejuvenating northward through Central Asia since the Miocene as a distant effect of the ongoing indentation of India into Eurasia. This deformation resulted in transpressive mountain building and roughly $2 \mathrm{~km}$ of denudation of the northern Kyrgyz Tien Shan, in particular the mountain ranges around the Issyk-Kul micro-continent since the Late Miocene. The low-temperature thermochronology results also indicate a rejuvenation trend of ages from the north and south toward the central Kyrgyz Tien Shan mountain rages (fig. 8) that might point to an exhumed flower structure within the current transpressive to purely compressive tectonic framework.

\section{Conclusions}

In the Tien Shan, strong earthquakes and their triggered land-slides have been recorded within the fault zones which separate the ancient micro-continents presently migrating and moving in different directions and at different velocities. In the Cenozoic, two factors affected the structure and geodynamics of the Tien Shan: overthrusting of the Pamirs and underthrusting of the Tarim plate. These two processes were responsible for the formation of different structural-geodynamic provinces separated by the Talass-Fergana fault zone. The mantle plume activity beneath the Tien Shan resulted in the tectonic layering of the lithosphere and fast movement of the upper crust $(10-15 \mathrm{~km})$ over the plume head and its deformation. We believe that these tectonic and geodynamic processes for the complicated modern structure of the Northern Tien Shan and are still active. For example, the Issyk-Kul micro-continent had been a homogenous structure during a long time period, and the deformation reached its central part as late as Quaternary. At present, the strongest 
deformation processes are recorded along the micro-continent margins forming a system of thrusts and promoting the further subsidence of the Issyk-Kul lake bottom and formation of a pull-apart structure [Buslov et al., 2003, 2007].

Anticlockwise rotation of the Tien Shan block continued and dextral strike-slip displacement along the Talass-Fergana fault zone occurred at rates of about 10-15 mm/yr. Finally, interplay of the Tarim and Pamir convergence with the Tien Shan ( $5 \mathrm{Ma}$ ago to the present) gave rise to the maximum uplift and formation of the modern Tien Shan as they occur today, while the dextral strike-slip displacement along the Talass-Fergana fault zone fell to $\sim 1 \mathrm{~mm} /$ yr [Zubovich et al., 2001].

The thrusting of the Tarim plate underneath the Tien Shan resulted in the shortening of the upper crust at a rate of $\sim 10-15 \mathrm{~mm} / \mathrm{yr}$, whereas India moves northward at $50 \mathrm{~mm} / \mathrm{yr}$. A certain amount of the strain induced by the ongoing convergence may have been accommodated by the tectonic layering of the Tien Shan crust and lithosphere and the presence of viscous, plastic layers in the Tien Shan crust. The upper crustal strain has been buffered to a large extent by the Issyk-Kul micro-continent and the surrounding mobile belts. It therefore becomes clear that the recent tectonics of the northern Tien Shan is controlled by its pre-Cenozoic structure. Earthquakes of $\mathrm{M}>6$ clearly mark the northern and southern margins of the lens-shaped Issyk-Kul micro-continent, indicating that crustal heterogeneity affected the formation of the active northern Kyrgyz Tien Shan structures. Seismic and magneto-telluric studies show the tectonic layering of the Tien Shan lithosphere, with several nearly horizontal viscous layers. The lower layer is underthrust northward into the northern Tien Shan middle crust, as indicated by the seismic data shown in this paper. Tectonic layering of the lithosphere beneath the Tien Shan implies the existence of horizontal viscous layers, possibly related to the rotation of the SW Tien Shan block, and also to the underthrusting of the Tarim plate and indentation of its basement into the middle crust of Tien Shan. This caused high slip rates and failure in the upper crust to depths of $20-30 \mathrm{~km}$.

Similarly to the Tien Shan, the strongest earthquakes and the highest-rate modern displacements are concentrated along the margins of micro-continents (micro-plates) in Altai as a result of the interaction of the Junggar and Tuva-Mongolian micro-continents.

\section{Acknowledgments}

The authors are supported by grants of the Fund for Scientific Research(FWO, Belgium) (JDG) and Russian Academy Scientist (ONZ-10.3)

\section{References}

Abad, I., Gutiérez-Alonso, G.Nieto, F.Gertner, I.Becker, A.Cabero , The structure and the phyllosilicates (chemistry, crystallinity and texture) of Talas Ala-tau (Tien Shan, Kyrgyz Republic): comparison with more recent subduction complexes, Tectonophysics, Vol.365, 2003, p.103-127.

Abdrakhmatov, K.E., Aldazhanov, S.A., Hager, B.H., Hamburger, M.W., Herring, T.A., Kalabaev, K.B., Makarov, V.I., Molnar, P., Panasyuk, S.V., Prilepin, M.T., Reilinger, R.E., Sadybakasov, I.S., Souter, B.J., Trapeznikov, Yu. A., Tsurkov, V.E., Zubovich, A.V., Relatively recent construction of the Tian Shan inferred from GPS 
measurements of present-day crustal deformation rates, Nature, Vol.384, 1996, p.450-453.

Abdrakhmatov K. Ye., Weldon R., Thompson S., Burbank D., Rubin C., Miller M., Molnar P., Onset, style and current rate of shortening in the central Tien Shan, Kyrgyz republic, Russian Geology and Geophysics ,Vol.42, 2001, p. 1585-1609.

Abdrakhmatov K.Y., Djanuzakov K.D., Delvaux D., Active tectonics and seizmic hazard of the Issyk-Kul basin in the Kyrgyz Tian-Shan. In: Klerkx J., Imanackunov B. (Eds), Lake Issyk-Kul: its natural environment. Kluwer Academic Publishers, Dordrecht, 2002, p. 147-160.

Abramowski U., Bergau A., Seebach D., Zech R., Glaser B., Sosin P., Kubik P.W., Zech W. , Pleistocene glaciations of Central Asia: results from ${ }^{10}$ Be surface exposure ages of erratic boulders from the Pamir (Tajikistan), and the Alay-Turkestan range (Kyrgyzstan), Quaternary Science Reviews, Vol. 25, 2006, p.1080-1096.

Aitchison J.C., Ali J.R., Davis A.M., When and where did India and Asia collide?, eburnal of Geophysical Research, vol. 212, BO5423, 2007, doi:10.1029/2006JB004706.

Allen M.B., Vincent S.J., Fault reactivation in the Junggar region, northwest China: the role of basement structures during Mesozoic-Cenozoic compression, eburnal of the Geological Society, London, Vol. 154, 1997, p. 151-155.

Allen M.B., Windley B.F., Zhang Chi, Palaeozoic collisional tectonics and magmatism of the Chinese Tien Shan, Central Asia, Tectonophysics, Vol.220, 1992, p. 89-115.

Allen M.B., Vincent, S.J. Wheeler P.J. Late Cenozoic tectonics of the Kepingtage thrust zone: interactions of the Tien Shan and Tarim Basin, northwest China, Tectonics , Vol.18, 1999, p. 639-654.

Allen M.B., Alsop G.I., Zhemchuzhnikov V.G., Dome and basin refolding and transpressive inversion along the Karatau fault System, southern Kazakstan, eburnal of the Geological Society, London 158, 2001, p.83-95.

Avouac J.P., Tapponnier P. Kinematic model of active deformation in Central Asia, Geophysical Research Letters, Vol. 20, 1993, p. 895-898.

Avouac J.P., Tapponnier P., Bai M., You H., Wang, G., Active thrusting and folding along the Northern Tien Shan, and Late Cenozoic rotation of the Tarim relative to Dzungaria and Kazakhstan, eburnal of Geophysical Research, Vol. 98, 1993, p. 67556804.

Bakirov A.B., Lesik O.M., Lobanchenko A. P., Sabitova T.M., Evidences for the modern deep-seated magmatism in Tien Shan, Russian Geology and Geophysics, Vol. 37, 1996, p. $42-53$.

Bazhenov M.L., Collins A.Q., Degtyarev K.E., Levashova N.M., Mikolaichuk A.V., Pavlov V.E., Van der Voo R., Paleozoic northward drift of the North Tien Shan (Central Asia) as revealed by Ordovician and Carboniferous paleomagnetism, Tectonophysics, Vol. 366, 2003, p. 113-141.

Bielinski R.A., Park S.K., Rybin A., Batalev V., Jun S., Sears, C., Lithospheric heterogeneity in the Kyrgyz Tien Shan imaged by magnetotelluric studies. Geophysical Research Letters, Vol.30, No.15, 2003, doi:10.1029/2003GL017455, p.4 .

Bourdeau C., Havenith H.B., Site effects modelling applied to the slope affected by the Suusamyr earthquake (Kyrgyzstan, 1992), Engeneering Geology, Vol.97, 2008, p. 126145. 
Bowman D., Korjenkov A., Porat N., Late-Pleistocene seismites from Lake Issyk-Kul, the Tien Shan range, Kyrghyzstan, Sedimentary Geology, Vol.163, 2004, p. 211-228.

Bragin V.D., Batalev V.Yu., Zubovich A.V., Lobanchenko A.N., Rybin A.K., Trapeznikov Yu. A., Qualitative bearing of modern movements on the deep geo-electric structure of the earth's crust in the Central Tian Shan and distribution of seicmicity, Russian Geology and Geophysics, Vol.42, 2001, p.1610-1629.

Brookfield M.E., Geological development and Phanerozoic crustal accretion in the western segment of the southern Tien Shan (Kyrgyzstan, Uzbekistan and Tajikistan), Tectonophysics , Vol. 328, 2000, p.1-14.

Bullen M.E., Burbank D.W., Garver J.I., Abdrakhmatov K,Ye., Late Cenozoic tectonic evolution of the northwestern Tien Shan: New age estimates for the initiation of mountain building, Geological Society of America Bulletin, Vol. 113, 2001, p.1544-1559.

Bullen M.E., Burbank D.W., Garver J.I., Building the Northern Tien Shan: integrated thermal, structural and topographic constraints, eburnal of Geology, Vol.111, 2003, p. 149-165.

Burbank D.W., McLean J.K., Bullen M., Abdrakhmatov K.Y., Miller M.M., Partitioning of intramontane basins by thrust related folding, Tien Shan, Kyrgyzstan. Basin Research, Vol.11, 1999, p. 75- 92.

Burtman V.S., Cenozoic crustal shortening between the Pamir and Tien Shan and a reconstruction of the Pamir-Tien Shan transition zone for the Cretaceous and Palaeogene, Tectonophysics, Vol.319, 2000, p.69-92.

Burtman V.S., Skobelev S.F., Molnar P., Late Cenozoic slip on the Talas-Ferghana faults, the Tien Shan, Central Asia, Geological Society of America Bulletin, Vol.108, 1996, p. 10041021.

Buslov M.M. Cenozoic tectonics of Central Asia: basement control, Himalayan eburnal of Science, Vol. 21, Issue 41, 2004, p. 104-105.

Buslov M.M., Zykin V.S., Novikov I.S., Delvaux D., Cenozoic history of the Chuya depression (Gorny Altai): Structure and Geodynamics, Russian Geology and Geophysics, Vol. 40, No.12, 1999, p. 1687-1701.

Buslov M.M., Klerkx, J., Abdrakhmatov K., Delvaux D., Batalev V.Yu., Kuchai O.A., Dehandschutter B., Muraliev A., Recent strike-slip deformation of the northern Tien Shan. In: Storti, F., Holdsworth, R.E., Salvini, F. (Eds). Intraplate strike-slip deformation belts. Geological Society of London, Special Publication, Vol. 210, 2003, p.53-64.

Buslov M.M., De Grave J., Bataleva E.V., Cenozoic tectonics and geodynamic evolution of the Tien Shan mountain belt, Himalayan eburnal of Sciences, Vol. 2, 2004, p. 106-107.

Buslov M.M, De Grave J., Bataleva E.A.V., Batalev V.Yu., Cenozoic tectonic and geodynamics in the Tian Shan: synthesis of geology and geophysical data, eburnal of Asian Earth Sciences, Vol. 29, 2007, p. 205-214.

Buslov M.M., Kokh D.A., De Grave J., Mesozoic-Cenozoic tectonics and geodynamics of the Altai, Tien Shan, and northern Kazkhstan, from apatite fission-track data, Russian geology and geophysical, Vol.49,No.9, 2008,p.648-654.

Carroll A.R., Graham S.A., Hendrix M.S., Ying D., Zhou,D., Late Paleozoic tectonic amalgamation of northwestern China: sedimentary record of the northern Tarim, northwestern Turpan and southern Junggar basins, GSA Bulletin, Vol. 107 , No.5, 1995, p. 571-594. 
Charreau J., Chen Y., Gilder S., Dominguez S., Avouac J.-P., Sen S., Sun D., Li Y., Wang W.M., Magnetostratigraphy and rock magnetism of the Neogene Kuitun He section (northwest China): implications for Late Cenozoic uplift of the Tianshan mountains, Earth and Planetary Science Letters, Vol. 230, 2005, p.177-192.

Charreau J., Gilder S., Chen Y., Dominguez S., Avouac J.-P., Sen S., Jolivet M., Li Y., Wang W., Magnetostratigraphy of the Yaha section, Tarim basin , China): $11 \mathrm{Ma}$ acceleration in erosion and uplift of the Tian Shan mountains, Geology, Vol. 34, 2006, p.181-184.

Chedia O.K., Morphology and neotectonics of the Tien Shan. Ilim. Press, Frunze, 1986 (in Russian).

Chen C., Lu H., Jia, D., Cai D., Wu, S., Closing history of the southern Tianshan oceanic basin, western China: an oblique collisional orogeny, Tectonophysics, Vol. 302, 1999, p. 23-40.

Chen Y., Cogné J.-P., Courtillot V., Avouac J.-P., Tapponnier, P., Wang G., Bai M., You H., Li M., Wei C., Buffetaut E., Paleomagnetic study of Mesozoic continental sediments along the northern Tien Shan (China) and heterogeneous strain in Central Asia, eburnal of Geophysical Research, Vol.96, 1991, p. 4065-4082.

Cobbold P.R., Davy P., Indentation tectonics in nature and experiment. 2. Central Asia. Bulletin of the Geological Institutions of Uppsala, Vol.14, 1988, p. 143-162.

Cobbold P.R., Sadybakasov E., Thomas J.C., Cenozoic transpression and basin development, Kyrghyz Tienshan, Central Asia. In: Roure, F., Ellouz, N., Shein, V.S., Skvortsov, I (Eds) Geodynamic evolution of sedimentary basins, International Symposium. Moscow, 1994, p. 181-202.

Cogné J.-P., Chen Y., Courtillot V., Rocher F., Wang G., Bai M., You H., A paleomagnetic study of Mesozoic sediments from the Junggar and Turfan basins, northwestern China., Earth and Planetary Science Letters, Vol.133, 1995, p.353-366.

Coutand I., Strecker M.R., Arrowsmith J.R., Hilley G. Thiede R.C., Korjenkov A., Omuraliev M., Late Cenozoic tectonic development of the intramontane Alai Valley, (PamirTien Shan region, central Asia): an example of intracontinental deformation due to the Indo-Eurasian collision, Tectonics, Vol. 21, No. 6, 2002, 1053, doi:10.1029/2002TC001385, p.19.

De Batist M., Imbo Y., Vermeersch P., Klerkx J., Giralt S., Delvaux D., Lignier V., Beck C., Kalugin I., Abdrakhmatov K.Y., Bathymetry and sedimentary environments of Lake Issyk-Kul, Kyrgyz Republic (Central Asia): a large, high-altitude, tectonic lake. In: Klerkx, J., Imanackunov, B. (eds), Lake Issyk-Kul: its natural environment. Kluwer Academic Publishers, Dordrecht, 2002, p. 101-123.

De Grave J., Van den haute P., Denudation and cooling of the Lake Teletskoye region in the Altai Mountains (South Siberia) as revealed by apatite fission-track thermochronology, Tectonophysics, Vol. 349, 2002, p. 145-159.

De Grave J., Buslov M.M., Van den haute P., Intracontinental deformation in Central Asia: distant effects of India-Eurasia convergence revealed by apatite fission-track thermochronology, Himalayan eburnal of Sciences, Vol. 2, 2004, p.121-122.

De Grave, J., Buslov, M.M., Van den haute, P., Distant effects of India-Eurasia convergence and Mesozoic intracontinental deformation in Central Asia: Constraints from apatite fission-track thermochronology, eburnal of Asian Earth Sciences, Vol. 29, 2007a., p. 188-204. 
De Grave J., Buslov M.M., Van den haute P., Dehandschutter B., Delvaux D., Meso-Cenozoic evolution of mountain range - intramontane basin systems in the southern Siberian Altai Mountains by apatite fission-track thermochronology. In: Lacombe, O., Lavé, J., Roure, F., Vergés, J. (Eds). Thrust belts and foreland basins: from fold kinematics to hydrocarbon systems. Frontiers in Earth Sciences, Springer Book Series, BerlinHeidelberg, chapter 24, 2007b, p.457-470.

De Grave J., Van den haute P., Buslov M.M., Dehandschutter B., Apatite fission-track thermochronology applied to the Chulyshman Plateau, Siberian Altai Region, Radiation Measurements, Vol. 43, 2008, p. 38-42.

Delvaux D., Abdrakhmatov K., Lemzin I.N., Strom A.L., Landslides and surface breaks of the $1911 \mathrm{Ms}=8.2$ Kemin earthquake, Kyrgyzstan, Russian Geology and Geophysics , Vol.42, 2001, p.1667-1677.

Delvaux D., Abdrakhmatov K., Lemzin I.N., Strom A.L., Kuchai O., Vittori T., Active tectonic deformation in the northern Tien-Shan of Kyrgyzstan. European Geosciences Union 1st General Assembly, 26-30 April, Geophysical Research Abstracts , Vol. 6, 2004, 06350.

Dill H.G., Kadirov O., Tsoy Y., Usmanov A. , Palaeogeography of Neogene red bed sequences along the Aksa-Ata river in the Parkent-Nurekata intramontane basin (Tien Shan Mountains, Uzbekistan): with special reference to the magnetic susceptibility of siliciclastic rocks, eburnal of Asian Earth Sciences, Vol. 29, 2007, p. 960-977.

Djenchuraeva R.D., Borisov, F.I., Pak N.T., Malyukova N.N., Metallogeny and geodynamics of the Aktiuz-Boordu mining district, northern Tien Shan, Kyrgyzstan, eburnal of Asian Earth Sciences , Vol.32, 2008, p. 280-299.

Dobretsov N.L., Buslov M.M., Delvaux D., Berzin N.A., Ermikov V.D., Meso- and Cenozoic tectonics of the Central Asian mountain belt: effects of lithospheric plate interaction and mantle plumes, International Geology Review, Vol. 38, 1996, p.430-466.

England P., Houseman G., Extension during continental convergence, with application to the Tibetan Plateau, eburnal of Geophysical Research, Vol.94, 1989, p.17561-17579.

Fu B., Lin A., Kano K., Maruyama T., Guo J., Quaternary folding of the eastern Tien Shan, northwest China, Tectonophysics, Vol.369, 2003, p.79-101.

Gao Jun, Li Maosong, Xiao Xuchang, Tang Yaoqing, He Guoqi , Paleozoic tectonic evolution of the Tienshan orogen, northwestern China, Tectonophysics, Vol.287, 1998, p. 213231.

Graham S.A., Hendrix M.S., Wang L.B., Carroll A.R., Collisional successor basins of western China: impact of tectonic inheritance on sand composition, GSA Bulletin, Vol.105, 1993, p. 323-344.

Heermance R.V., Chen J., Burbank D.W., Wang C., Chronology and tectonic controls of Late Tertiary deposition in the SW Tian Shan foreland, NW China, Basin Reasearch, Vol.19, 2007, p. 599-632.

Hendrix M.S., Evolution of Mesozoic sandstone compositions, southern Junggar, northern Tarim, and western Turpan basins, northwest China: a detrital record of the ancestral Tian Shan, eburnal of Sedimentary Research, Vol.70, No. 3, 2000, p. 520-532.

Hendrix M.S., Graham S.A., Carroll A.R., Sobel E.R., McKnight C.L., Schulein B.J., Wang Z., Sedimentary record and climatic implications of recurrent deformation in the Tian 
Shan: evidence from Mesozoic strata of the north Tarim, south Junggar, and Turpan basins, NW China, GSA Bulletin, Vol.104, 1992, p.53-79.

Hendrix M.S., Dumitru T.A., Graham S.A., Late Oligocene - Early Miocene unroofing in the Chinese Tien Shan: an early effect of the India-Asia collision, Geology , Vol.22, 1994, p. 487-490.

Huang B., Piper J.D.A., Peng S., Liu T., Li Z., Wang Q., Zhu, R., Magnetostratigraphic study of the Kuche depression; Tarim Basin, and Cenozoic uplift of the Tian Shan range, western China, Earth and Planetary Science Letters, Vol.251, 2006, p.346-364.

Hubert-Ferrari A., Suppe J., Gonzalez-Mieres R., Wang X., Mechanisms of active folding of the landscape (southern Tian Shan, China), cburnal of Geophysical Research, Vol.112, B03S09, 2007, p. 39 .

Ji, J., Luo P., White P., Jiang H., Gao L., Ding Z., Episodic uplift of the Tianshan Mountains since the late Oligocene constrained by magnetostratigraphy of the Jingou River section, in the southern margin of the Junggar Basin, China. Journal of Geophysical Research 113, 2008, B05102.

John T., Klemd, R., Gao J., Garbe-Schönberg C.D., Trace-element mobilization in slabs due to non steady-state fluid-rock interaction: constraints from an eclogite-facies transport vein in blueschist (Tianshan, China), Lithos, Vol. 103, 2008, p.1-24.

Jolivet M., Ritz J.-F., Vassallo R., Larroque C., Braucher R., Todbileg M., Chauvet A., Sue C., Arnaud N., De Vicente R., Arzhanikova A., Arzhanikov S. , Mongolian summits: an uplifted, flat, old but still preserved erosion surface, Geology , Vol. 35, 2007, p. 871874.

Ketcham R.A., Donelick R.A., Donelick M.B., AFTSolve: A program for multi-kinetic modeling of apatite fission-track data, Geological Materials Research, Vol. 2, 2000, p.1-32.

Khudoley A.K., Structural and strain analysis of the middle part of the Talassian Alatau ridge (Middle Asia, Kirgizstan), eburnal of Structural Geology , Vol.15, 1993, p.693706.

Klerkx J., Abdrakhmatov K., Buslov M., De Batist M., Vermeesch P., Imbo Y., Hus R. and Delvaux,D. , Active deformation in the Issyk-Kul basin (Kyrghyz Tian Shan): from pull-apart to transpressional ramp basin, Second Intern. Congress of Limno-geology, Brest, Abstract Book, 1999,T36.

Konopelko D., Biske G., Seltmann R., Eklund O., Belyatsky B., Hercynian post-collisional Atype granites of the Kokshaal Range, Southern Tien Shan, Kyrgyzstan, Lithos, Vol. 97, 2007, p.140-160.

Koppes M., Gillespie A.R., Burke R.M., Thompson S.C., Stone J., Late Quaternary glaciation in the Kyrgyz Tien Shan, Quaternary Science Reviews , Vol.27, 2008, p.46-866.

Korzhenkov A.M., Cenozoic tectonics and seismicity of the northwestern part of the IssykKul basin (Tian Shan), Russian Geology and Geophysics , Vol. 41, 2000, p.971-982.

Kröner A., Hegner E., Lehmann B., Heinhorst J., Wingat, M.T.D., Liu D.Y., Ermelov, P., Palaeozoic arc magmatism in the Central Asian Orogenic Belt of Kazakhstan: SHRIMP zircon ages and whole-rock Nd isotopic systematics, eburnal of Asian Earth Sciences, Vol. 32, 2008, p.118-130.

Laslett G.M., Green P.F., Duddy I.R., Gleadow A.J.W., Thermal annealing of fission tracks in apatite. 2. A quantitative analysis, Chem. Geol. , Vol. 65, 1987, p.1-13. 
Laurent-Charvet S., Charvet J., Shu, L. Ma R., Lu H., Palaeozoic late collisional strike-slip deformations in Tianshan and Altay, Eastern Xinjiang, NW China, Terra Nova, Vol. 14, 2002, p. 249-256.

Lei J., Zhao D., Teleseismic P-wave tomography and the upper mantle structure of the Central Tien Shan orogenic belt, Physics of the Earth and Planetary Interiors, Vol.162, 2007, p.165-185.

Le Pichon, X., Fournier M., Jolivet, L., Kinematics, topography, shortening and extrusion in the India-Eurasia collision, Tectonics , Vol.11, 1992, p. 1085-1098.

Levashova N.M., Mikolaichuk A.V., McCausland P.J.A., Bazhenov M.L., Van der Voo, R., Devonian paleomagnetism of the North Tien Shan: implications for the middleLate Paleozoic paleogeography of Eurasia, Earth and Planetary Science Letters, Vol. 257, 2007, p.104-120.

Li Z., Song, W. Peng, S., Wang,D., Zhang Z. , Mesozoic-Cenozoic tectonic relationships between the Kuqa subbasin and Tian Shan, northwest China: constraints from depositional records, Sedimentary Geology, Vol.172, 2004, p. 223-249.

Lukk A.A., Yunga S.L., Shevchenko V.I., Hamburger M.W., Earthquake focal mechanisms, deformation state, and seismotectonics of the Pamir-Tien Shan region, Central Asia, eburnal of Geophysical Research, Vol.100, 1995, p.20321-20343.

Mao J., Konopelko D., Seltmann R., Lehmann B., Chen W., Wang Y., Eklund O., Usubaliev T., Postcollisional age of the Kumtor gold deposit and timing of Hercynian events in the Tien Shan, Kyrgyzstan, Economic Geology, Vol.99, 2004, p. 1771-1780.

Meade B.J., Hager B.H., The current distribution of deformation in the Western Tien Shan from block models constrained by geodetic data, Russian Geology and Geophysics , Vol.42, 2001, p.1622-1633.

Mercier J.L., Armijo R., Tapponnier P., Carey-Gailhardis E., Han T.L., Change from late Tertiary compression to Quaternary extension in southern Tibet during India-Asia collision, Tectonics, Vol.6, 1987, p.275-304.

Métivier F., Gaudemer Y., Mass transfer between eastern Tien Shan and adjacent basins (central Asia): constraints on regional tectonics and topography, Geophysical eburnal International, Vol.128, 1997, p. 1-17.

Mikolaichuk A.V., The structural position of thrusts in the recent orogen of the central Tian Shan, Russian Geology and Geophysics, Vol.41, 2000, p. 961-970.

Molnar P., Tapponnier P., Cenozoic tectonics of Asia: Effects of a continental collision, Science, Vol.189, 1975, p.419-426.

Neil E.A., Houseman G.A., Geodynamics of the Tarim Basin and the Tian Shan in central Asia, Tectonics, Vol. 16, 1997, p.571-584.

Oskin M.E., Burbank D., Transient landscape evolution of basement-cored uplifts: example of the Kyrgyz Range, Tian Shan, eburnal of Geophysical Research, Vol.112, F03S03, 2007, p. 20.

Pavlis T.L., Hamburger M.W., Pavlis G.L., Erosional processes as a control on the structural evolution of an actively deforming fold and thrust belt: an example from the PamirTien Shan region, central Asia, Tectonics, Vol.16, 1997, p.810-822.

Pirajno F., Mao J., Zhang,Zh., Zhang Zu., Chai F. , The association of mafic-ultramafic intrusions and A-type magmatism in the Tian Shan and Altay orogens, NW China: implications for geodynamic evolution and potential for the discovery of new ore deposits, cburnal of Asian Earth Sciences, Vol.32, 2008, p. 165-183. 
Reigber C., Michel G.W., Galas R., Angermann D., Klotz J., Chen J.Y., Papschev A., Arslanov R., Tzurkov V.E., Ishanov M.C. , New space geodetic constraints on the distribution of deformation in Central Asia, Earth and Planetary Science Letters , Vol.191, 2001, p.157-165.

Rybin A., Spichak V., Batalev V., Schelochkov G., Bataleva E., Safronov I., Magnetotelluric investigations of an active thrust fault in the Northern Tien Shan, Kyrgyzstan, Central Asia, Proceedings of the 17th Workshop on Electromagnetic Induction in the Earth, Hyderabad, India, 2004, p. 6.

Rybin A., Spichak V., Batalev V., Bataleva E., Matyukov V.E., Array magnetotelluric soundings in the active seismic area of northern Tien Shan, Russian Geology and Geophysics , Vol.49, 2008, p. 337-349.

Sabitova, T.M., Adamova, A.A., Seismic tomography study of the Tien Shan crust: (results, problems, and prospects), Russian Geology and Geophysics, Vol.42, 2001, p.1543-1553.

Sobel E.R., Dumitru T.A. , Thrusting and exhumation around the margins of the western Tarim Basin during the India-Asia collision, eburnal of Geophysical Research ,Vol.102, 1997, p. 5043-5064.

Sobel E., Chen J., Heermance R.V., Late Oligocene-Early Miocene initiation of shortening in the SW Chinese Tian Shan: implications for Neogene shortening rate variations, Earth and Planetary Science Letters , Vol.247, 2006, p.70-81.

Solomovich L.I., Postcollisional magmatism in the South Tien Shan Variscan orogenic belt, Kyrgyzstan: evidence for high-temperature and high-pressure collision, eburnal of Asian Earth Sciences , Vol.30, 2007, p.142-153.

Solomovich L.I., Trifonov B.A., Postcollisional granites in the South Tien Shan Variscan collisional belt, Kyrgyzstan, eburnal of Asian Earth Sciences, Vol.21, 2002, p. 7-21.

Sun J., Zhu, R., Bowler J., Timing of the Tianshan Mountains uplift constrained by magnetostratigraphic analysis of molasse deposits, Earth and Planetary Science Letters, Vol.219, 2004, p.239-253.

Tapponnier P. and P. Molnar, Active faulting and Cenozoic tectonics on the Tien Shan, Mongolia and Baikal regions, I Geophys. Res., Vol.84, 1979, p. 3425-3459.

Tatevossian R.E., The Verny, 1887, earthquake in Central Asia: application of the INQUA scale, based on coseismic environmental effects, Quaternary International, Vol.173174,2007 , p. 23-29.

Thompson S.C., Weldon R.J., Rubin C.M., Abdrakhmatov K., Molna, P., Berger G.W., Late Quaternary slip rates across the central Tien Shan, Kyrgyzstan, Central Asia, eburnal of Geophysical Research , Vol.107, B9, 2203, doi:10.1029/2001JB000596, 2002, p. 32 .

Tibaldi A., Graziotto E., Forcella F., Gapich V.H., Morphotectonic indicators of Holocene faulting in Central Tien Shan, Kazakstan, and geodynamic interpretations, eburnal of Geodynamics , Vol.23, 1997, p.23-45.

Trapeznikov Yu.A., Andreeva E.V., Batalev V.Yu., Berdichevsky M.N., Van'jan L.L., Volykhin A.M., Golubtsova N.S., Rybin A.K., Magneto-telluric soundings in the Kyrgyz Tien Shan Mts, Izvestija Academii Nauk SSSR, ser. Fizika Zemli , Vol.1, 1997., p.3-20 (in Russian with English abstract).

Trofimov A.K., Quaternary deposits of the Issyk-Kul basin and their relation to tectonics, Izvetija Academii Nauk Kyrgyzskoy SSR, Vol.1, 1990, p.87-95 (in Russian with English abstract). 
Tychkov S.A., Kuchai O.A., Bushenkova N.A., Bragin V.D., Kalmetieva Z.A. , Current crustal deformation in the northern Tien Shan: GPS and seismological data., Russian Geology and Geophysics , Vol.49, 2008, p.280-290.

Van der Beek P., Delvaux D., Andriessen P.A.M., Levi K.G., Early Cretaceous denudation related to convergent tectonics in the Baikal region, SE Siberia, I Geol. Soc. London, Vol.153, 1996, p. 515-523.

Van der Voo, R., Levashova N.M., Skrinnik L.I., Kara T.V., Bazhenov M.L., Late orogenic large-scale rotations in the Tien Shan and adjacent mobile belts in Kyrgyzstan and Kazakhstan, Tectonophysics, Vol.426, 2006, p. 335-360.

Vassallo R., Jolivet M., Ritz J.-F., Brauchner R., Larroque C., Sue C., Todbileg M., Javkhlanbold D., Uplift age and rates of the Gurvan Bogd system (Gobi-Altay) by apatite fission track analysis, Earth and Planetary Science Letters , Vol.259, 2007, p. 333-346.

Vinnik L.P., Reigber C., Aleshin I.M., Kosarev G.L., Kaban M.K., Oreshin S.I., Roecker S.W., Receiver function tomography of the Central Tien Shan, Earth and Planetary Science Letters, Vol.225, 2004, p. 131-146.

Wang C.-Y., Yang Z.-E., Luo H., Mooney W.D. , Crustal structure of the northern margin of the eastern Tien Shan, China, and its tectonic implications for the 1906 M 7.7 Manas earthquake, Earth and Planetary Science Letters, Vol.223, 2004, p. 187-202.

Wang B., Chen Y., Zhan S., Shu L., Faure M., Cluzel D., Charvet J., Laurent-Charvet S., Primary Carboniferous and Permian paleomagnetic results from the Yili block (NW China) and their implications on the geodynamic evolution of Chinese Tianshan belt, Earth and Planetary Science Letters , Vol.263, 2007a, p.288-308.

Wang B., Shu L.S., Cluzel D., Faure M., Charvet J. , Geochemical constraints on Carboniferous volcanic rocks of the Yili block (Xinjiang, NW China): implications for the tectonic evolution of western Tianshan, eburnal of Asian Earth Sciences , Vol.29, 2007b, p. 148-159.

Yang Y., Liu M., Cenozoic deformation of the Tarim plate and the implications for mountain building in the Tibetan Plateau and the Tian Shan, Tectonics , Vol.21, 1059, doi:10.1029/ 2001TC001300, 2002, p.17.

Yang T.N., Wang Y., Li, J.Y., Sun G.H., Vertical and horizontal strain partitioning of the central Tianshan (NW China): evidence from structures and ${ }^{40} \mathrm{Ar} /{ }^{39} \mathrm{Ar}$ geochronology, eburnal of Structural Geology, Vol.29, 2007, p.1605-1621.

Yin A, Nie S., Craig P., Harrison T.M., Ryerson F.J., Qian X., Yang G. , Late Cenozoic tectonic evolution of the southern Chinese Tian Shan, Tectonics, Vol.17, No.1, 1998, p.1-27.

Yuan W.-M., Carter A., Dong J.-Q., Bao Z., An Y., Guo, Z., Mesozoic-Tertiary exhumation history of the Altai Mountains, northern Xinjiang, China: new constraints from apatite fission track data, Tectonophysics , Vol.412, 2006, p.183-193.

Zhang C., Zhai M., Allen M.B., Saunders A.D., Wang G., Huang X., Implications of Palaeozoic ophiolites from western Junggar, NW China, for the tectonics of Central Asia, eburnal of the Geological Society, London, Vol.150, 1993, p.551-561.

Zhang, L., Ellis, D.J., Jiang, W. Ultra-high pressure metamorphism is western Tianshan, China: Part I. Evidence from inclusions of coesite pseudomorphs in garnet and from quartz exsolution lamellae in omphacite in eclogites. American Mineralogist $87,2002 a, 853-860$. 
Zhang L., Ellis D.J., Williams S., Jiang W., Ultra-high pressure metamorphism is western Tianshan, China: Part II. Evidence from magnesite in eclogite, American Mineralogist, Vol.87, 2002b, p.861-866.

Zhao J., Zhou S., He Y., Ye Y., Liu S. , ESR dating of glacial tills and glaciation in the Urumqi river headwaters, Tianshan Mountains, China, Quaternary International, Vol.144, 2006, p.61-67.

Zubovich A.V., Trapeznikov Yu.A., Bragin V.D., Mosienko O.I., Shchelochkov G.G., Rybin A.K. and Batalev V.Yu., Deformation field, Earth's crust deep structure, and spatial seismicity distribution in the Tian Shan, Russian Geology and Geophysics, Vol. 42, 2001, p.1634-1640. 


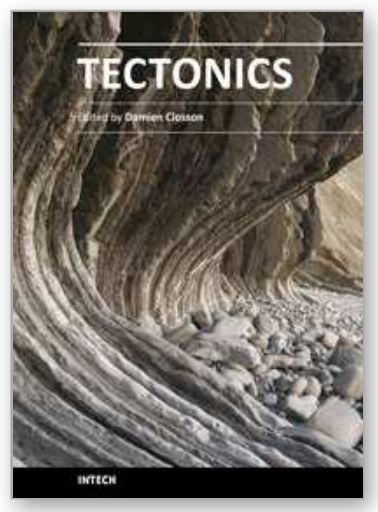

\author{
Tectonics \\ Edited by Dr. Damien Closson
}

ISBN 978-953-307-545-7

Hard cover, 358 pages

Publisher InTech

Published online 28, February, 2011

Published in print edition February, 2011

The term tectonics refers to the study dealing with the forces and displacements that have operated to create structures within the lithosphere. The deformations affecting the Earth's crust are result of the release and the redistribution of energy from Earth's core. The concept of plate tectonics is the chief working principle.

Tectonics has application to lunar and planetary studies, whether or not those bodies have active tectonic plate systems. Petroleum and mineral prospecting uses this branch of knowledge as guide. The present book is restricted to the structure and evolution of the terrestrial lithosphere with dominant emphasis on the continents. Thirteen original scientific contributions highlight most recent developments in seven relevant domains: Gondwana history, the tectonics of Europe and the Near East; the tectonics of Siberia; the tectonics of China and its neighbourhood; advanced concepts on plate tectonics are discussed in two articles; in the frame of neotectonics, two investigation techniques are examined; finally, the relation between tectonics and petroleum researches is illustrated in one chapter.

\title{
How to reference
}

In order to correctly reference this scholarly work, feel free to copy and paste the following:

Buslov, Mikhail M. and De Grave, Johan (2011). Seismic Hazard in Tien Shan: Basement Structure Control Over the Deformation Induced by Indo-Eurasia Collision, Tectonics, Dr. Damien Closson (Ed.), ISBN: 978-953307-545-7, InTech, Available from: http://www.intechopen.com/books/tectonics/seismic-hazard-in-tien-shanbasement-structure-control-over-the-deformation-induced-by-indo-eurasia-

\section{INTECH}

open science | open minds

\section{InTech Europe}

University Campus STeP Ri

Slavka Krautzeka 83/A

51000 Rijeka, Croatia

Phone: +385 (51) 770447

Fax: +385 (51) 686166

www.intechopen.com

\section{InTech China}

Unit 405, Office Block, Hotel Equatorial Shanghai

No.65, Yan An Road (West), Shanghai, 200040, China

中国上海市延安西路65号上海国际贵都大饭店办公楼 405 单元

Phone: +86-21-62489820

Fax: $+86-21-62489821$ 
(C) 2011 The Author(s). Licensee IntechOpen. This chapter is distributed under the terms of the Creative Commons Attribution-NonCommercialShareAlike-3.0 License, which permits use, distribution and reproduction for non-commercial purposes, provided the original is properly cited and derivative works building on this content are distributed under the same license. 